\title{
The Challenge of Reducing Subsidies and Trade Barriers
}

\author{
Kym Anderson
}

University of Adelaide, World Bank and CEPR

kanderson@worldbank.org

\begin{abstract}
World Bank Policy Research Working Paper 3415, September 2004
The Policy Research Working Paper Series disseminates the findings of work in progress to encourage the exchange of ideas about development issues. An objective of the series is to get the findings out quickly, even if the presentations are less than fully polished. The papers carry the names of the authors and should be cited accordingly. The findings, interpretations, and conclusions expressed in this paper are entirely those of the authors. They do not necessarily represent the view of the World Bank, its Executive Directors, or the countries they represent. Policy Research Working Papers are available online at http://econ.worldbank.org.
\end{abstract}

One of 10 Challenge Papers prepared for the Copenhagen Consensus project presented at a Roundtable in Copenhagen, 24-28 May 2004. Thanks are due to Jan Pronk and Arvind Panagariya for helpful comments at the Roundtable, to numerous colleagues for their ideas and suggestions, to Denmark's Environmental Assessment Institute and The Economist for sponsoring the project, and to Lona Fowdur for research assistance with the spreadsheet underlying Figure 1. Forthcoming in Global Crisis, Global Solutions, edited by B. Lomborg, Cambridge and New York: Cambridge University Press, 2004. 


\begin{abstract}
This is one of ten studies for the Copenhagen Consensus Project that sought to evaluate the most feasible opportunities to improve welfare globally and alleviate poverty in developing countries. It argues that phasing out distortionary government subsidies and barriers to international trade will yield an extraordinarily high benefit-cost ratio. A survey is provided of recent estimates, using global economy wide simulation models, of the benefits of doing that via the current Doha round of multilateral trade negotiations. Even if adjustment costs are several times as large as suggested by available estimates, the benefit-cost ratio from seizing this opportunity exceeds 20 . That is much higher than the rewards from regional or bilateral trade agreements or from providing preferential access for least-developed countries' exports to high-income countries. Such reform would simultaneously contribute to alleviating several of the other key challenges reflected in the United Nations' Millennium Development Goals.
\end{abstract}

Key words: trade policy reform, subsidy reduction, Doha Development Agenda

JEL codes: F02, F13, F15, F17

\title{
Contact author:
}

Kym Anderson

Development Research Group

Mailstop MC3-303

World Bank

1818 H Street NW

Washington DC 20433 USA

Phone +1 2024733387

Fax +12025221159

kanderson@worldbank.org 


\title{
The Challenge of Reducing Subsidies and Trade Barriers
}

\author{
Kym Anderson
}

The Copenhagen Consensus project is looking for an answer to the question: If there was a desire to spend US\$50 billion over the next five years to improve the world, what opportunity offers the highest payoff? This paper argues that putting effort into phasing out wasteful subsidies and trade barriers should be ranked highly among the opportunities being addressed in this project, for three reasons:

- It would require only a small fraction of that $\$ 50$ billion to make a significant impact in this area via greater advocacy, and cuts to subsidies could reduce government outlays by hundreds of millions of dollars, leaving plenty to spend on the next-best opportunity;

- Trade reform would allow citizens also to spend more on other pressing problems (because under freer trade the world's resources would be allocated more efficiently), thereby indirectly contributing to opportunities to alleviate other challenges; and

- Trade reform would also directly alleviate poverty and thereby reduce environmental degradation and address some of the other challenges identified in this project, namely climate change, communicable diseases, conflicts and arms proliferation, education under-investment, financial instability, poor governance and corruption, population and migration issues, water issues, and under-nutrition and hunger.

\section{The challenge}

Despite the net economic and social benefits of reducing most government subsidies ${ }^{1}$ and opening economies to trade, almost every national government intervenes in markets for goods and services in ways that distort international commerce. Those distortionary policies harm most the economies imposing them, but the worst of them (in agriculture and clothing) are particularly harmful to the world's poorest people. The challenge addressed in this paper is to rid the world of such wasteful and anti-poor policies. The geographic scope is thus global, although some of the opportunities for alleviating the problem involve action by just subsets of the world's national governments.

\footnotetext{
${ }^{1}$ Not all subsidies are welfare-reducing, and in some cases a subsidy-cum-tax will be optimal to overcome a gap between private and social costs that cannot be bridged à la Coase (1960). Throughout this paper all references to 'cutting subsidies' refer to bringing them back to their optimal level (which will be zero in all but those exceptional cases).
} 
To keep the task manageable, the policy instruments considered will be limited to those trade-related ones over which a government's international trade negotiators have some influence both at home and abroad. That thereby excludes measures such as generic taxes on income, consumption and value added, government spending on mainstream public services, infrastructure and generic social safety nets in strong demand by the community, and subsidies (taxes) and related measures set optimally from the national viewpoint to overcome positive (negative) environmental or other externalities. Also excluded from consideration here are foreign exchange policies.

This challenge in its modern form has been with us for about 75 years. The latter part of the nineteenth century saw a strong movement toward laissez faire, but that development was reversed following the first world war in ways that led to the Great Depression of the early 1930s and the conflict that followed (Kindleberger 1989). It was during the second world war, in 1944, that a conference at Bretton Woods proposed an International Trade Organization. An ITO charter was drawn up by 1948 along with a General Agreement on Tariffs and Trade (GATT), but the ITO idea died when the United States failed to progress it through Congress (Diebold 1952). Despite that, the GATT during its 47-year history (before it was absorbed into the World Trade Organization (WTO) on 1 January 1995) oversaw the gradual lowering of many tariffs on imports of manufactured goods by governments of developed countries. Manufacturing tariffs remained high in developing countries, however, and distortionary subsidies and trade policies affecting agricultural and services markets of both rich and poor countries continued to hamper efficient resource allocation, economic growth and poverty alleviation.

The Uruguay Round of multilateral trade negotiations led to agreements signed in 1994 that have seen some trade liberalization over the subsequent 10 years. But even when those agreements are fully implemented by end-2004, and despite additional unilateral trade liberalizations since the 1980 s by a number of countries (particularly developing and transition economies), many subsidies and trade distortions will remain. They include not just trade taxes-cum-subsidies but also contingent protection measures such as anti-dumping, regulatory standards that can be technical barriers to trade, and domestic production subsidies (allegedly decoupled in the case of some farm support programs but in fact only partially so). Insufficient or excessive taxation or quantitative regulations in the presence of externalities such as pollution also lead to inefficiencies and can be trade distorting. Furthermore, the on-going proliferation of preferential trading and bilateral or regional integration arrangements - for which there would be little or no need in the absence of trade barriers - is adding complexity to international economic relations. In some cases those arrangements are leading to trade and investment diversion rather than creation.

The reluctance to reduce trade distortions is almost never because such policy reform involves government treasury outlays. On the contrary, except in the case of a handful of low-income countries still heavily dependent on trade taxes for government revenue, such reform may well benefit the treasury (by raising income and/or consumption tax revenues more than trade tax revenues fall, not to mention any payments foregone because of cuts to subsidy programs). Rather, distortions remain largely because further trade liberalization and subsidy cuts redistribute jobs, income and wealth in ways that those in government fear will reduce their chances of remaining in power (and 
possibly their own wealth in countries where corruption is rife). The challenge involves finding politically attractive ways to phase out remaining distortions to world markets for goods, services, capital and potentially even labor.

This paper focuses primarily on distortions at national borders (trade taxes and subsidies, quantitative restrictions on international trade, and technical barriers to trade) plus a few significantly trade-distorting production subsidies. While global in coverage, the paper distinguishes between policies of developed countries and those of developing (including former socialist and least-developed) countries. Among other things, it emphasizes the consequences, in the absence of other policy changes, for the UN's key Millennium Development Goals as encapsulated in the other nine challenges being addressed by the Copenhagen Consensus project - since trade reform, perhaps more than any of the other opportunities under consideration, has the potential to impact positively on most of those challenges.

The paper is structured as follows. Section 2 summarizes the arguments for removing trade distortions, along with critiques by sceptics. This includes examining not only the economic benefits, and costs but also the social and environmental consequences of such reform, to make the case that opening markets is a worthy cause. Four opportunities to reduce these distortions over the next five years are then laid out in Section 3. They are, in decreasing order of potential contribution to global openness and economic growth: full trade liberalization globally (to provide more a benchmark than a politically likely scenario), non-preferential legally binding trade liberalization following the WTO's current Doha round of multilateral trade negotiations, a reciprocal preferential agreement in the form of a Free Trade Area of the Americas (FTAA), and a nonreciprocal preferential agreement by OECD countries to provide least-developed countries with duty-free market access for their exports of everything but arms (EBA). ${ }^{2}$ The core of the paper is Section 4, where estimates of the economic benefits and costs of these opportunities are presented, along with a methodological critique of the various empirical studies surveyed, an assessment of the likely social and environmental consequences of reducing subsidies and trade barriers, ${ }^{3}$ and finally an overall net present value assessment.

\footnotetext{
${ }^{2}$ A non-preferential but non-binding trade liberalization opportunity by the Pacific rim members of APEC is also mentioned in Section 3, but it is not considered in detail because its time frame is to 2020 and in any case it is a subset of the opportunity to move to global free trade.

${ }^{3}$ Throughout the paper, governmental 'triple bottom line' terminology is used to distinguish economic effects from social and environmental effects, rather than the economist's standard terminology of private effects for the former and social effects for the latter.
} 


\section{The arguments for (and against) removing subsidies and trade barriers}

Even before examining the empirical estimates of the costs and benefits from grasping various trade-liberalizing opportunities, the case can be made that such reform in principle is beneficial economically. It then remains to examine whether particular reforms are also at least benign in terms of social and environmental outcomes. The latter is particularly important because there are many non-economists who believe or assume the social and/or environmental consequences are adverse and seek to persuade others through such means as mass (and sometimes violent) street protests.

\subsection{Static economic gains from own-country reform}

The standard comparative static analysis of national gains from international trade emphasizes the economic benefits from production specialization and exchange so as to exploit comparative advantage in situations where a nation's costs of production and/or preferences differ from those in the rest of the world. This is part of the more general theory of the welfare effects of distortions in a trading economy, as summarized by Bhagwati (1971). Domestic industries become more productive as those with a comparative advantage expand by drawing resources from those previously protected or subsidized industries that grow slower or contract following reform.

The static gains from trade tend to be greater as a share of national output the smaller the economy, particularly where economies of scale in production have not been fully exploited and where consumers (including firms importing intermediate inputs) value variety so that intra- as well as inter-industry trade can flourish. ${ }^{4}$ In such cases the more-efficient firms within expanding industries tend to take over the less efficient ones. Indeed theory and empirical studies suggest the shifting of resources within an industry may be more welfare-improving than shifts between industries. ${ }^{5}$ They are also greater the more trade barriers have allowed imperfect competition to prevail in the domestic marketplace, which again is more common in smaller economies where industries have commensurately smaller numbers of firms.

\subsection{Dynamic economic gains from own-country reform}

To the standard comparative static analysis needs to be added links between trade and economic growth. The mechanisms by which openness contributes to growth are

\footnotetext{
${ }^{4}$ Some may question the value of intra-industry trade, given that transaction costs such as freight can be non-trivial, but consumers are willing to pay for a greater variety of products. Those consumers include producers using those products as intermediate inputs. Feenstra et al. (1992) suggest the welfare cost of tariff protection can be underestimated by as much as a factor of ten when this consideration is not included. In a study of US import data from 1972 to 2001, Broda and Weinstein (2004) find that the upward bias in the conventional import price index, because of not accounting for the growth in varieties of products, is approximately 1.2 percent per year, and suggest that the welfare gain from variety growth in US imports alone is 2.8 percent of GDP.

${ }^{5}$ See Melitz (1999) on the theory of this point and Trefler (2001) for an empirical illustration.
} 
gradually getting to be better understood by economists, thanks to the pioneering work of such theorists as Grossman and Helpman (1991), Rivera-Batiz and Romer (1991) and the literature those studies spawned. In a helpful survey of the subsequent literature, Taylor (1999) identifies several channels through which openness to trade can affect an economy's growth rate. They include the scale of the market when knowledge is embodied in the products traded, the degree of redundant knowledge creation that is avoided through openness (Romer 1994), and the effect of knowledge spillovers. ${ }^{6}$ More importantly from a policy maker's viewpoint, the available empirical evidence strongly supports the view that open economies grow faster (see the survey by USITC 1997).

Notable econometric studies of the linkage between trade reform and the rate of economic growth include those by Sachs and Warner (1995) and Frankel and Romer (1999). More recent studies also provide some indirect supportive econometric evidence. For example, freeing up the importation of intermediate and capital goods promotes investments that increase growth (Wacziarg 2001). Indeed, the higher the ratio of imported to domestically produced capital goods for a developing country, the faster it grows (Lee 1995; Mazumdar 2001). Rodriguez and Rodrik (2001) examine a number of such studies and claim the results they surveyed are not robust. However, in a more recent study that revisits the Sachs and Warner data and then provides new time-series evidence, Wacziarg and Welch (2003) show that dates of trade liberalization do characterize breaks in investment and GDP growth rates. Specifically, for the 1950-1998 period, countries that have liberalized their trade (raising their trade-to-GDP ratio by an average of 5 percentage points) have enjoyed on average 1.5 percentage points higher GDP growth compared with their pre-reform rate. There have also been myriad case studies of liberalization episodes. In a survey of 36 of them, Greenaway (1993) reminds us that many things in addition to trade policies were changing during the studied cases, so ascribing causality is not easy. That, together with some econometric studies that fail to find that positive link, has led Freeman (2003) to suggest the promise of raising the rate of economic growth through trade reform has been overstated. The same could be (and has been) said about the contributions to growth of such things as investments in education, health, agricultural research, and so on (Easterly 2001). A more-general and more-robust conclusion that Easterly draws from empirical evidence, though, is that people respond to incentives. Hence getting incentives right in factor and product markets is crucial - and removing unwarranted subsidies and trade barriers is an important part of that process. Additional evidence from 13 new case studies reported in Wacziarg and Welch (2003) adds further empirical support to that view, as does the fact that there are no examples of autarkic economies that have enjoyed sustained economic growth, in contrast to the many examples since the 1960s of reformed economies that boomed after opening up.

Specifically, economies that commit to less market intervention tend to attract more investment funds, ceteris paribus, which raise their stocks of capital (through greater aggregate global savings or at the expense of other economies' capital stocks). More-open economies also tend to be more innovative, because of greater trade in intellectual capital (information, ideas and technologies, sometimes but not only in the

\footnotetext{
${ }^{6}$ Openness allows society's knowledge capital to grow faster. If an $\mathrm{x}$ percent increase in that stock generates an increase of more than x percent in individual firms' outputs, as assumed by Romer (1986) and Lucas (2002), then that economy's GDP growth rate will rise.
} 
form of purchasable intellectual property). Trade liberalization can thereby lead not just to a larger capital stock and a one-off increase in productivity but also to higher rates of capital accumulation and productivity growth in the reforming economy because of the way reform energizes entrepreneurs. For those higher growth rates to be sustained, though, there is widespread agreement that governments also need to (a) have in place effective institutions to efficiently allocate and protect property rights, (b) allow domestic factor and product markets to function freely, and (c) maintain macroeconomic and political stability (Rodrik 2003; Wacziarg and Welch 2003; Baldwin 2004). Or to paraphrase Panagariya (2004), trade openness is necessary, but may not be a sufficient condition, for sustained economic growth.

\subsection{Why, then, are countries protectionist?}

Despite the evident economic gains from removing trade distortions, most countries retain protection from foreign competition for at least some of their industries. Numerous reasons have been suggested as to why a country imposes trade barriers in the first place (infant industry assistance, unemployment prevention, balance of payments maintenance, tax revenue raising, protection of environmental or labor standards, etc.). All of them are found wanting in almost all circumstances in that a lower-cost domestic policy instrument is available to meet each of those objectives (Corden 1997; Bhagwati 1988), but nonetheless there are well-meaning people who still believe trade measures are needed for one or other of those reasons or to avoid the social costs associated with removing them. So part of the present challenge is to convince such people that the gains from reform would far exceed the costs and that there are more-direct means of addressing their concerns.

The more difficult part of reforming trade policies relates to the fact that the most compelling explanation for their persistence is a political economy one. The changes in product prices that result from trade liberalization or subsidy cuts necessarily change the prices for the services of productive factors such as land, labor and capital. Hence even though the aggregate income and wealth of a nation may be expected to grow when trade distortions are reduced, not everyone need gain and social safety nets, where they exist, typically provide only partial compensation for such losses. This is the source of resistance to policy reforms: the expected losses in jobs, income and wealth are concentrated in the hands of a few who are prepared to support politicians who resist protection cuts, while the gains are sufficiently small per consumer and export firm and are distributed sufficiently widely as to make it not worthwhile for those potential gainers (not to mention foreign producers/exporters) to get together to lobby for reform, particularly given their greater free-rider problem in acting collectively (Hillman 1989; Grossman and Helpman 1994). Thus the observed pattern of protection in a country at a point in time may well be an equilibrium outcome in a national political market for policy intervention. In that case reform requires a shock to that equilibrium. 


\subsection{What can induce reductions in subsidies and trade barriers?}

That political market equilibrium may indeed be altered from time to time. Changes are induced by such things as better information dissemination, technological changes, reforms abroad, and new opportunities to join international trade agreements.

\subsubsection{Better information dissemination}

One way that political markets for policy intervention change is better dissemination (e.g., by national or international bureaucrats, think tanks, local export industries, foreign import suppliers) of more-convincing information on the benefits to consumers, exporters and the overall economy from reducing subsidies and trade distortions, and on alternative means of achieving society's other objectives more efficiently, so as to balance the views of single-issue non-government organizations (NGOs), labor unions and the like who tend to focus only on the (often over-stated) costs of reform to their constituents. During the past two decades the spreading of more balanced benefit/cost information has contributed to unilateral economic reforms and a consequent opening to trade in numerous developing countries as well as richer countries such as Australia and New Zealand. More recently several major NGOs, together with the OECD Secretariat, have begun to focus on providing better information about the wastefulness of environmentally harmful subsidies that has already started to have an impact (e.g. in reducing coal mining subsidies in Europe).

\subsubsection{Technological change}

Another way the political equilibrium is altered is technological innovation. The information and telecommunications revolution of the past two decades, for example, has dramatically lowered the costs of doing business across national borders, just as happened with the arrival of steamships and the telegraph during the latter part of the nineteenth century. That increased trading opportunity has made (actual or potential) exporters more eager to get together to counter the anti-trade lobbying of importprotected groups and NGOs.

\subsubsection{Unilateral opening of markets abroad}

A country's political equilibrium could be upset also by trade opening by one or more other countries, in so far as those reforms alter international prices and volumes of trade and foreign investment and provide greater market access opportunities for exporters. Such opening abroad also adds to the evidence of the net gains and (particularly in the case of phased reforms) the relatively low adjustment costs associated with trade reform, making it easier for exporters to counter the alarmist lobbying of protectionists.

A coincidence of this and the previous two types of shocks has given rise to the latest wave of globalization. This is raising not only the rewards to economies practicing good economic governance but also the cost of retaining poor economic governance. Just as financial capital can now flow into a well-managed economy more easily and quickly 
than ever before, so it can equally quickly be withdrawn if confidence in that economy's governance is shaken - as the East Asian financial crisis of the late 1990s demonstrated all too clearly. A crucial element of good economic governance is a commitment to a permanently open international trade and payments regime (along with sound domestic policies such as an absence of subsidies, secure property rights and prudent monetary and fiscal policies).

\subsubsection{Opportunities to join international trade agreements}

In seeking to find politically expedient ways to open their economies, governments are increasingly looking for opportunities to do so bilaterally, regionally or multilaterally. The reason is that the political market equilibrium in two or more countries can be altered in favor of liberalism through an exchange of product market access. If country A allows more imports, it may well harm its import-competing producers if there are insufficient compensation mechanisms; but if this liberalization is done in return for country A's trading partners lowering their barriers to A's exports, the producers of those exports will be better off. The latter extra benefit may be sufficiently greater than the loss to A's import-competing producers that A's liberalizing politicians too become net gainers in terms of electoral, financial or other support in return for negotiating a trade agreement. When politicians in the countries trading with A also see the possibility for gaining from such an exchange of market access, for equal and opposite reasons, prospects for trade negotiations are ripe. ${ }^{7}$

Such gains from trade negotiations involving exchange of market access are potentially greater nationally and globally, the larger the number of countries involved and the broader the product and issues coverage of the negotiations. That is the logic behind negotiating multilaterally with nearly 150 WTO member countries over a wide range of sectors and issues. That WTO process is becoming increasingly cumbersome, however, which has led countries also to negotiate bilaterally or regionally in the hope that faster and deeper integration will result. Preferential free trade areas involving just a subset of countries need not be welfare-enhancing for all participant nations, however, because of trade diversion away from the lowest-cost supplier; and non-participants in the rest of the world may be made worse off too (Pomfret 1997; Schiff and Winters 2003). Hence the need for empirical analysis of the likely gains from different types of prospective trade agreements.

\subsection{What about the social and environmental consequences of trade reform?}

Trade liberalization in recent years has attracted a considerable amount of attention of NGOs, as witnessed by their presence on the streets of cities where trade ministers meet (e.g., during the WTO Ministerial in Seattle in late 1999). The groups attracted see trade reform as contributing to the spread of capitalism and in particular of multinational firms, and believe those aspects of globalization add to innumerable social and environmental ills in both rich and poor countries. But just as the traditional

\footnotetext{
${ }^{7}$ Elaborations of this economists' perspective can be found in Grossman and Helpman (1995), Hillman and Moser (1995), Maggi and Rodrigeuz-Clare (1998), and Hoekman and Kostecki (2001). Political scientists take a similar view. See, for example, Goldstein (1998).
} 
economic arguments for protection have been found wanting, so too have the social and environmental ones both conceptually and empirically. For example, there has not been a systematic 'race to the bottom' in environmental or labor standards of rich countries as a result of trade and foreign direct investment growth, and in poor countries foreign corporations often have among the highest environmental and labor standards (Bhagwati and Hudec 1996). Nor has trade growth been a major contributor to the stagnation of wages of unskilled workers in OECD countries (Greenaway and Nelson 2002).

The number of such claims by anti-globalization groups - almost invariably not supported by credible empirical evidence - makes it a huge task to address them all systematically. However, some attention is given in Section 4.3 below to the social and environmental benefits and costs associated with cutting subsidies and trade barriers, with the focus on their potential impacts on the other nine challenges being addressed in this project. 


\section{The opportunities for reducing subsidies and trade barriers}

The gains from reducing government interventions in markets have been well known since the writing of Adam Smith's Wealth of Nations more than two centuries ago, and popular magazines such as The Economist and more and more daily newspapers continue to remind the public of the virtues of market opening. ${ }^{8}$ Even so, greater dissemination of empirical information on the net economic benefits of reducing trade distortions, to balance the often-exaggerated claims by potential losers and their supporters of the adjustment costs of reform, can no doubt assist the liberalization process. Empirical studies can also shed better light and take some of the heat out of debates about whether, in the presence of domestic distortions such as undertaxed pollution, subsidy and trade reform is welfare-reducing. Such studies can also point to the domestic policy reforms that should accompany trade reform so as to guarantee not only national welfare improvement in aggregate but also that there is no significant left-behind group, no unexpected new damage to the environment, etc. Clearly there is an opportunity for well-meaning interest groups, think tanks and national and international economic agencies to spend more money and resources on such empirical studies, and in particular on the effective dissemination of their findings. In an idealistic world in which such studies were able to persuade all governments to fully liberalize their trade unilaterally, the benefit derived from that opportunity would be measured by the gain from moving the world to one free of subsidies and trade barriers (Opportunity 1). Unlikely though such an outcome may seem in the foreseeable future, it provides a benchmark against which all other opportunities to partially meet this challenge can be measured.

Among the more-feasible opportunities available today for encouraging trade negotiations to stimulate significant market opening, the most obvious is a nonpreferential legally binding partial trade liberalization following the WTO's current round of multilateral trade negotiations (Opportunity 2). That round was launched in Doha, the capital of Qatar, in 2001 with the intention of completing negotiations at the end of 2004, when implementation of the last of the Uruguay Round commitments under WTO are scheduled to be completed. It now seems uncertain as to how long the current round will take, what issues will be kept on its agenda, and indeed even whether it will come to a successful conclusion. That uncertainty is all the more reason for assessing the potential of this opportunity, given that it involves almost 150 WTO member countries plus another 25 in the midst of accession, and hence all but a tiny fraction of global trade.

There are at least three other types of trade negotiating opportunities that, while they involve only a subset of the world's economies, have the potential to generate deeper integration in the medium term and so are worth comparing to the WTO Doha round. One is non-preferential but non-binding trade liberalization, as currently being pursued by the Pacific rim members of the Asia Pacific Economic Cooperation (APEC) forum. APEC member countries agreed in 1994, and have since reiterated that commitment several times, to move to free trade in the Asia Pacific region by 2010 in the

\footnotetext{
${ }^{8}$ On the intellectual history of the virtues of free trade, see Bhagwati (1988, Ch. 2) and Irwin (1996). Bhagwati notes that the virtues of division of labour and exchange were cited twenty four centuries ago in Plato's Republic (see the back cover of the October 1985 issue of the Journal of Political Economy).
} 
case of developed countries and 2020 in the case of developing countries. Even though there is no legal binding on members to achieve that goal and retain that status beyond the deadline, the distinguishing feature of this long-term commitment is that, as with WTO commitments, the market opening is to be provided to all trading partners of each APEC country (a most-favored-nation or MFN reform) and not just to other APEC members as in a free trade agreement (FTA). That makes its effects simply a subset of those derived from moving to global free trade, so the APEC initiative can be considered as part of Opportunity 1.

A second type of trade negotiating opportunity involving a subset of the world's economies is a reciprocal preferential agreement. This could take the form of an FTA, a customs union, or a broader economic union. Typically such an agreement would be legally binding and, even though it would be notified to the WTO, it would provide greater market access only to signatories to that agreement and hence would not be MFN. An example is the agreed enlargement of the European Union from 15 to 25 members, which is to be implemented from May 2004. Even though implementation will be spread over the next few years, for present purposes enlarging the EU to 25 is considered an opportunity already seized rather than in prospect (and further eastern enlargement is unlikely before the next decade). Efforts are also being made to negotiate a Free Trade Area of the Americas (FTAA), which potentially would bring together all the economies of North, Central and South America. This is by far the largest and most ambitious preferential agreement currently in prospect: it dwarfs the bilateral FTA negotiations the US and EU are having with a range of other countries, and it is also more advanced than other proposed FTAs such as in South Asia and between China and Southeast Asia. Hence the FTAA provides an upper limit on the gains that might be expected from this type of trade agreement (Opportunity 3).

There is also the opportunity to enter into non-reciprocal preferential trade agreements, as the EU has with its former colonies (the so-called ACP countries of Africa, the Caribbean and the Pacific) and as most OECD countries have with developing countries in the form of a Generalized System of tariff Preferences (GSP). The EU's recent initiative to extend preferences for UN-designated 'least developed countries' (LDCs) provides duty- and quota-free access to the EU for exports of 'everything but arms' (EBA). It received in-principle, best-endeavors endorsement by other OECD countries at the WTO Ministerial in Doha in November 2001, but without any specific timetable. While this opportunity (Opportunity 4) clearly involves only a small volume of global trade, it has a relatively high probability of being implemented unilaterally by numerous countries and is perceived to be of direct benefit to the world's poorest people - even though that view may be misplaced (see section 4.1 .5 below). 


\section{Benefits and costs of reducing subsidies and trade barriers}

To estimate the benefits and costs associated with the opportunities just outlined, this section first looks at economic benefits, particularly for halving subsidies and trade barriers by 2010. That is a rather optimistic scenario for the Doha round (Opportunity 2), but one that is not politically infeasible if enough resources were to be expended globally to alter the balance of power between narrow pro-protection private interest groups and broader community interests in free trade. The economic costs associated with that strategy are then examined, followed by an assessment of its social and environmental benefits and costs, before concluding as to the overall net present value and benefit/cost ratio for society from reducing subsidies and trade barriers.

\subsection{Economic benefits from opportunities to reduce subsidies and trade barriers}

\subsubsection{The computable general equilibrium approach to measuring economic benefits}

All the estimates considered below of the potential global economic welfare gains from these opportunities are generated using computable general equilibrium (CGE) models of the global economy, the most common of which (GTAP) is described in the Appendix. The CGE welfare gains refer to the equivalent variation in income (EV) as a result of each of the shocks described. ${ }^{9}$ While not without their shortcomings (see Francois 2000, Whalley 2000, Anderson 2003 and the list of caveats in Section 4.1.7), CGE models are far superior for current purposes to partial equilibrium models, which fail to capture the economy-wide nature of the adjustments to reform whereby some sectors expand when others contract and release capital and labor; and they are also superior to macroeconometric models which typically lack sufficient sectoral detail (Francois and Reinert 1997). They were first used in multilateral trade reform analysis in ex post assessments of the Tokyo Round of GATT negotiations in the late 1970s/early 1980s (Cline et al. 1978; Deardorff and Stern 1979, 1986; Whalley 1985). Since then they have been used increasingly during and following the Uruguay Round, as shown, for example, in the various studies summarized in Martin and Winters (1996).

Empirical comparative static studies of the economic welfare gains from trade liberalization typically generate positive gains for the world and for most participating countries. (Exceptions are when a country's welfare is reduced more by a terms of trade change or reduced rents from preferential market access quotas than it is boosted by improvements due to reallocating its resources away from protected industries.) When economies of scale and monopolistic competition (IRS/MC) are assumed instead of constant returns to scale and perfect competition (CRS/PC), and when trade in not just goods but also services is liberalized, the estimates of potential gains can be increased several fold. A few economists have also examined the effects of lowering barriers to international capital flows or labor movements, and some have included estimates of a lowering of trade costs as a result of trade facilitation measures such as streamlining

\footnotetext{
${ }^{9} \mathrm{EV}$ is defined as the income that consumers would be willing to forego and still have the same level of well-being after as before the reform. For a discussion of the merits of EV versus other measures of change in economic welfare, see for example Just, Hueth and Schmitz (1982), Ng (1983) and Martin (1997).
} 
customs-clearance procedures. Even so, in most studies the sum of these comparative static CGE model estimates tends to amount to only a tiny fraction of GDP.

Those low estimated gains seem to fly in the face of casual empiricism. Irwin (2002), for example, notes that three different countries on three continents chose to liberalize in three different decades, and per capita GDP growth in each of those countries accelerated markedly thereafter (Korea from 1965, Chile from 1974 and India from 1991 - see Irwin 2002, Figures 2.3 to 2.5). Admittedly those historical liberalization experiences involved also complementary reforms to other domestic policies and institutions that would have contributed significantly to the observed boosts in economic growth. Even so, as mentioned in Section 2.2 above, both theoretical economists and econometricians have sought to demonstrate that trade can promote not only static efficiency gains but also dynamic gains. Some CGE modelers have tried to proxy that effect by adding an additional one-off total factor productivity shock to their trade reform scenarios. But reform may also raise the rate of factor productivity growth and/or of capital accumulation. Such endogenous growth has yet to be satisfactorily introduced into CGE models, ${ }^{10}$ and in any case it is unclear how to interpret a model's estimated welfare effects if households are reducing current consumption in order to boost their or their descendents' future consumption by investing more.

It should be kept in mind that all the experiments in the comparative static CGE studies surveyed below reduce only trade barriers plus agricultural production and export subsidies. The reasons for including subsidies only in agriculture are that they are the key subsidies explicitly being negotiated at the WTO (where non-agricultural export subsidies are illegal), ${ }^{11}$ they represented an estimated 38 percent of all government expenditure on subsidies globally during 1994-98, ${ }^{12}$ and they are fully represented in the GTAP database whereas subsidies for most other sectors are not included so it is not possible to estimate their welfare cost within the same framework. And the reason for not also explicitly estimating the welfare impacts of other domestic policies and institutions that, because of their complementarity, affect the payoff from opening up is that typically they are beyond the sphere of influence of international trade negotiators.

With this as background, consider first the economic benefits associated with each of the four opportunities in turn.

\subsubsection{Removing all trade barriers and agricultural subsidies globally}

Only a few CGE modeling studies have reported simulations of complete liberalization of trade. The ones of most relevance are those that incorporate in their

\footnotetext{
${ }^{10}$ For an early attempt to develop a dynamic version of the GTAP model, see Ianchovichina and McDougall (2000).

${ }^{11}$ Production subsidies in non-agricultural sectors, however, have come under close scrutiny through the WTO's dispute settlement procedures since the Uruguay Round's Agreement on Subsidies and Countervailing Measures came into force with the WTO's formation in 1995 (Bagwell and Staiger 2004). Also, fisheries subsidies are explicitly under consideration by negotiators in the WTO's Doha round.

12 See van Beers and de Moor (2001, Table 3.1), whose estimates suggest energy subsidies are the next biggest group, at 22 percent of all subsidies, followed closely by road transport ( 21 percent) and then water (6 percent), forestry and mining (each 3 percent) and fisheries ( 2 percent), with manufacturing subsidies making up the residual 5 percent. For more details on energy and transport subsidies, see OECD (1997) and von Moltke, McKee and Morgan (2004).
} 
baseline the implementation of all the Uruguay Round agreements, since that process is due for completion at the end of 2004. The results are reported in Table 1 and each study is discussed in turn.

The ADFHHM study (Anderson et al. 2002) provides the simplest scenario: global liberalization of just merchandise trade using a comparative static version of the GTAP model with constant returns to scale and perfect competition in all product and factor markets (first described in Hertel 1997). The GTAP Version 4 database (McDougall, Elberhnri and Truong 1998), which provides data for 1995, is used in that study to generate a new baseline for 2005 by projecting the world economy forward a decade and assuming all Uruguay Round commitments (including the politically sensitive Agreement on Textiles and Clothing) and those of China and Taiwan (made on their accession to the WTO) are implemented by then. This baseline for 2005 is then compared with how it would look after full adjustment following the removal of all countries' trade barriers and agricultural subsidies. The economic welfare gain is estimated to be US\$254 billion per year in 1995 dollars as of 2005 (and hence slightly more each year thereafter as the global economy expands). Of that, $\$ 108$ billion p.a. is estimated to accrue to developing countries. These are the lowest of the estimates summarized in Table 1. Using the decomposition algorithm developed by Harrison, Horridge and Pearson (2000), Table 2 shows that only two-fifths of this study's estimated gain to developing countries are derived from policy changes in developed countries. Changes in policies in developing countries make a more substantial contribution to other developing countries' economic welfare, and almost half of that gain comes from policy changes in their agricultural sector. This reflects the importance not only of own-country reform but also of expanding South-South trade.

The BDS study (Brown, Deardorff and Stern 2003) uses the same Version 4 GTAP data base also projected to 2005, but they embed it in their static Michigan Model of World Production and Trade (www.ssp.umich.edu/rsie/model and Deardorff and Stern 1986) to produce the highest of the surveyed estimates of global welfare gains from complete removal of trade barriers and agricultural subsidies: $\$ 2080$ billion p.a., of which $\$ 431$ billion would accrue to developing countries. These much larger estimates are the result of several features of this study: not having China and Taiwan's implementation of their WTO accession commitments in the baseline; the inclusion of increasing returns to scale and monopolistic competition (IRS/MC) for non-agricultural sectors and therefore product heterogeneity at the level of the firm rather than just the national industry; liberalization of services in addition to goods trade (with IRS/MC assumed for the huge services sector); and the inclusion in services liberalization of the opening to foreign direct investment. The latter boosts substantially the gains from services liberalization, which account for 63 percent or $\$ 1310$ of this study's estimated total gains.

All other estimates of the gains from complete trade liberalization are between these two extremes. The FMT study (Francois, van Meijl and van Tongeren 2003), which builds on Francois (2001), uses the more-recent Version 5.2 of the GTAP database for 1997 (Dimaranan and McDougall 2002) and a variant of the GTAP model to include IRS/MC (see www.intereconomics.com/francois and Francois 1998). As in the BDS study, the latter feature ensures the inclusion of the agglomeration effects of reform that 
are emphasized in the new economic geography literature. ${ }^{13}$ Its economic welfare gain is estimated to be US\$367 billion per year in 1997 dollars as of 1997, of which $\$ 113$ billion p.a. is estimated to accrue to developing countries. Just over 40 percent of that total $(\$ 151$ billion) is due to trade facilitation measures such as streamlining customs clearance, ${ }^{14}$ while only 14 percent ( $\$ 53$ billion) is due to services trade reform. The global gains from removing just merchandise trade barriers is $\$ 163$ billion in 1997 (compared with ADFHHM's gain of $\$ 254$ billion for 2005 when the global economy is considerably larger). Part of the reason for these gains being lower than those from the BDS study is that this one includes in its baseline China's WTO accession, the European Union's Agenda 2000 and the EU's eastern enlargement, which lowers its estimate of the gains from removing residual EU-25 trade barriers. But the main reason has to do with the quite different way in which services trade barriers are measured and their reform modeled.

The final study reported in Table 1, WBGEP (World Bank 2002), uses the same 1997 GTAP data base as FMT but projects the GTAP model to 2015. With the world economy considerably bigger then than in 1997 or 2005 one would expect WBGEP to provide larger dollar estimates, other things equal. Two are provided, both assuming constant returns to scale and perfect competition and both with only merchandise trade reformed. The first estimate, which is comparable to the ADFHHM study, provides a global gain of $\$ 355$ billion p.a. for 2015. That is in line with ADFHHM's estimate of \$254 billion for 2005 as both represent 0.7 percent of GDP for their respective years, as projected by the World Bank (2003, Table A3.1). The slightly larger share of that gain going to developing countries (52 percent in 2015 compared with ADFHHM's 43 percent) also is in line with the expected growth in developing countries' share of the world economy over that decade.

The second WBGEP estimate assumes liberalization boosts factor productivity in each industry according to the extent of growth in the share of production exported by the industry. While the precise formula used for this adjustment is somewhat arbitrary, it nonetheless gives a feel for how the overall size and composition across economies of the gains from trade can change when allowance is made for an openness-induced productivity boost. The case presented suggests the gains would rise 2.3 times to $\$ 832$ billion p.a. with that adjustment, ${ }^{15}$ and since trade of developing countries grows more than that of OECD countries under full liberalization, they receive 65 percent of those gains ( $\$ 539$ billion) instead of the 52 percent or $\$ 184$ billion generated without that productivity adjustment.

\footnotetext{
${ }^{13}$ See, for example, Fujita, Krugman and Venables (2001), Neary (2001), Fujita and Thisse (2002) and Baldwin et al. (2003).

${ }^{14}$ The OECD defines trade facilitation as the simplification and standardization of procedures and associated information flows required to move products internationally from seller to buyer and to pass payment in the other direction. For an in-depth discussion of the nature and importance of reducing trading costs, see World Bank (2003, Ch. 6). Francois et al. (2003) assume full trade liberalization would be accompanied by a reduction in trading costs (the difference between fob and cif valuations) of 3 percent of the value of trade.

15 This greater gain is consistent with the consensus that has developed over the past decade that incorporating endogenous growth effects in CGE models raises the welfare gains from trade liberalization by several orders of magnitude. A recent study by Rutherford and Tarr (2002), using a generic model of a small open economy, reinforces this consensus.
} 
In both WBGEP simulations, agriculture contributes 70 percent of the gains from liberalizing all merchandise trade. This is very similar to the estimate of two-thirds by both the ADFHHM and FMT studies. ${ }^{16}$ The extent to which these results are dominated by agriculture is remarkable, given that agriculture is responsible for only one-twelfth of global GDP and exports. It simply reflects the fact that agricultural sectors of both rich and poor countries are still highly protected from import competition, and in some rich countries are also subsidized directly, despite the efforts of the Uruguay Round.

By contrast to the similarity in welfare results for goods trade liberalization, the gain from services trade reform reported in the FMT study (\$53 billion in 1997) is only a small fraction of the BDS estimate of $\$ 1280$ billion in 2005 (\$220 billion of which goes to developing countries). The FMT estimate is in line with an estimate by Verikios and Zhang (2001) of $\$ 47$ billion globally just for telecom and financial services, while the BDS estimate of $\$ 220$ billion for developing countries alone is exceeded by the WBGEP study which also reports an estimate of the gain from liberalizing services trade just for developing countries, of $\$ 884$ billion in 2015 . These vastly different results for services reflect the great deal of uncertainty that still prevails in estimating the extent and effects of services trade barriers (see Findlay and Warren 2001; Whalley 2003). Even though this is widely recognized as a major area of trade policy concern for both developed and developing countries, there is clearly much more research required in this area before we can expect a convergence of empirical estimates for the services sector.

The huge estimate for gains from services reform in the BDS study appears to be a consequence of their model explicitly allowing for foreign investment flows, in contrast to the standard GTAP model where such flows play a very modest role. What this highlights is that trade in products need not - as suggested by the simplest of trade models (Mundell 1957) - be a complete substitute for trade in factors of production such as capital and labor. Indeed, as Markusen (1983) has shown (and see also Ethier 1996), factor trade can be a complement to product trade. Nor are we able to say a priori which might grow more when trade in all factors and products is opened simultaneously (Michaely 2003).

None of the above empirical studies examines the global welfare gains from allowing greater international movement of labor. Historical analyses of global migration by Hatton and Williamson $(1998,2002)$ conclude that the effective demand by developing country workers to move to higher-income countries is likely to grow considerably over the next quarter century, with wage differentials a major driving force. It appears national governments, however, are becoming more rather than less restrictive of migrant inflows in the wake of that growing demand. How costly are such restrictions? A CGE study twenty years ago suggested complete liberalization of world labor markets, in the presence of existing barriers to trade in products and capital, could double world income and in so doing raise several-fold the economic welfare of people working at that time in developing countries (Hamilton and Whalley 1984). The more-recent resurgence

\footnotetext{
${ }^{16}$ By contrast, BDS estimate a share close to zero. The explanation BDS provide for this result is that the expanding of agriculture in lightly protecting countries draws resources from the non-agricultural sectors which, unlike agriculture, are assumed to have increasing returns to scale and monopolistic competition. Apparently that IRS/MC feature is having a much stronger effect in the BDS model than it is in the FMT one (which also has IRS/MC), since the FMT estimated contribution of agriculture is close to the estimates from the CRS/PC models.
} 
of interest in this subject has encouraged one group of GTAP modelers to examine this issue afresh, but in the context of Mode 4 of the WTO's General Agreements on Trade in Services, the so-called temporary movement of natural persons. Winters et al. (2003) simulate the effect of raising worker immigration quotas of developed countries enough to increase labor forces there by 3 percent (which sums to a temporary migration flow from developing countries of 8.4 million unskilled and 8 million skilled workers or just 0.6 percent of the labor force in developing countries). A movement even as modest as that is estimated to raise annual world welfare by $\$ 156$ billion ( 0.6 percent of global income), with most of that benefit accruing to those currently in developing countries who migrate. These welfare results underscore two points: first, migration restrictions are very costly to people in poor countries; and second, if rich countries are to persist with those restrictions in the wake of growing demands for lifting them, even more effort should be made to alleviate poverty through liberalizing international capital flows and trade in products exportable from developing countries, most notably agricultural goods.

The above studies do not provide an estimate of the net welfare gains from reducing direct government subsidies to domestic production or consumption of non-farm products. They would be small compared with those from trade reform, bearing in mind that an estimated 38 percent of all government subsidies go to agriculture (van Beers and de Moor 2001) and hence are captured in the above estimates. They nonetheless represent significant transfers from taxpayers to special interest groups, estimated by van Beers and de Moor (2001, Table 3.1) to be $\$ 1065$ billion per year globally between 1994 and 1998 (4 percent of GDP) and by others to be between half and twice that amount. Cutting those subsidies therefore has the potential to provide a great deal of revenue for meeting society's other pressing challenges.

\subsubsection{Reducing trade barriers and agricultural subsidies following the WTO's Doha round}

The WTO is in the midst of its first round of multilateral trade negotiations following the Uruguay Round, whose implementation program is scheduled to be completed at the end of 2004. The present round, known as the Doha Development Agenda, is currently at an early stage, and even the list of issues to be negotiated is yet to be finalized, even though the round was originally scheduled to conclude at the end of 2004 presumably with implementation to begin in 2006 following ratification by national governments in 2005. Given the slow progress to date, assessing the likely benefits is therefore difficult, even though we know the potential benefits are those associated with full trade liberalization as discussed above.

Typically ex ante analyses by CGE modelers in this situation involve uniform across-the-board tariff cuts. The above-mentioned BDS study (Brown, Deardorff and Stern 2003), for example, reports a one-third cut in applied rates of protection and, because their model is linear, the results are simply one-third of those reported above. If their tariff cuts were 50 percent, they would generate a global welfare gain of $\$ 1030$ billion p.a. of which $\$ 216$ billion would accrue to developing countries. This is again hugely greater than what other analysts are reporting (Table 3 ).

For example, the FMT study reports a 50 percent across-the-board cut to tariffs and farm subsidies, plus half the liberalization in services and half the trade facilitation 
modeled for their full global liberalization reported above. The authors estimate a global welfare gain from that 50 percent reform of just $\$ 196$ billion per year, which is slightly over half their estimate for full liberalization although the component parts differ (e.g., the gain to developing countries would be 44 percent of that total, compared with only 31 percent of the gains from full reform). An important reason for this non-linearity is that FMT cut bound tariffs on merchandise by 50 percent, not the (often much lower) applied rates that typically are used by modelers including BDS. Since it is the rates that are bound in WTO commitments that are negotiated, this feature of FMT's study is more realistic. Of that $\$ 196$ billion, only 4 percent is due to the halving of domestic subsidies to agriculture. ${ }^{17}$

The FMT's global welfare gain is very similar to that estimated for a 50 percent across-the-board cut to tariffs and farm export subsidies by Harrison, Rutherford, Tarr and Gurgel (HRTG 2003). That is pure coincidence though, as there are some features of the HRTG study that would lead one to expect larger estimates (they use higher price elasticities than most other trade modelers, and cut applied rather than bound tariffs), and other features that would lower their estimates (they assume constant returns to scale, do not liberalize services trade or domestic farm subsidies, and there is no trade facilitation included).

On the one hand, all three of these studies are probably excessive in the sense that no previous multilateral trade reform has agreed to anywhere near as much as a 50 percent across-the-board cut in (especially applied) rates. ${ }^{18}$ On the other hand, these studies all underestimate the potential gains, perhaps by a wide margin, because they exclude any endogenous growth effects and effects of liberalization of trade in labor or capital (with the exception of the BDS study where FDI in services is allowed).

\subsubsection{Removing intra-American trade barriers following the FTAA negotiations}

The negotiations to create a Free Trade Area of the Americas (FTAA) - the largest such FTA negotiations currently under way or in prospect - have begun but are running into political problems so it is not clear if/when they might conclude. The reason for considering this opportunity here is simply to point out that the potential global gains from such an FTA are only a small fraction of those obtainable from multilateral negotiation (because the major economies of Europe and North America are already well integrated and so any new initiatives involve relatively small economies joining one of those hubs or integrating among themselves). Two studies that examine both Doha and the FTAA are reported in Table 3, together with one, by Hertel, Hummels, Ivanic, and Keeney (HHIK 2003), that looks just at the FTAA. The global gain from the FTAA in the

\footnotetext{
${ }^{17}$ That represents 15 percent of the gains from the agricultural portion of the reform. This is consistent with other studies which also find domestic support measures are a relatively minor part of agricultural assistance measures. See, for example, Hoekman, Ng and Olarreaga (2004) and Rae and Strutt (2003). Those findings vindicate the present paper's focus on border measures.

${ }^{18}$ Francois (2001) compares gains from a 50 percent cut in bound tariffs with a 50 percent cut in applied tariffs and finds the global gains from the former to be one-sixth less than from the latter. A complete elimination of agricultural export subsidies is conceivable, as could be true too for developed countries' tariffs on manufactures other than for textiles and clothing; but a halving of applied agricultural tariffs in this first WTO round seems unlikely, especially given the considerable extent to which bound tariffs exceed current applied rates.
} 
BDS study is estimated to be just one-twelfth of that from a 50 percent multilateral trade liberalization (hence one-sixth that from a 25 percent multilateral reform, etc.); and for the HRTG study the difference is even greater. Furthermore, these studies take no account of the dampening effect of the rules of origin that almost invariably constrain the extent to which firms can take advantage of any FTA's removal of bilateral tariffs (Krueger 1999; Anson et al 2003); nor of the fact that such FTAs typically have phase-in periods that stretch more than a decade for some products and exclude altogether the most sensitive products.

FTAs of this type are pursued nonetheless for a wide range of reasons, including preferential access to an important protected market (often at the expense of other countries), insurance against anti-dumping by that partner, and deeper and faster integration than has been possible or is in prospect through the multilateral reform route (Schiff and Winters 2003). The gains to just one or a few developing economies from joining with North America or the EU may be non-trivial, but so too would be the gains from a similar degree of multilateral reform. According to the HRTG study, a multilateral reform involving even just a 25 percent reduction in merchandise tariffs would benefit South America more than the FTAA, for example.

Moreover, even leaving aside the potential systemic cost of FTAs on the WTO rules-based multilateral trading system, such preferential agreements can harm excluded developing and/or developed countries through trade diversion. For example, the estimated gains to FTAA members are nearly fully offset by losses to excluded economies, according to the HHIK and HRTG studies. Harmful trade diversion would also result from an FTA between, say, South Asia and either North America or the EU, according to GTAP results reported in Bandara and $\mathrm{Yu}$ (2003). Indeed a recent examination of 18 existing preferential trading arrangements found that 12 diverted more merchandise trade from non-members than they created among members (Adams et al. 2003). That review was able to conclude more positively about the benefits of FTAs in reforming such things as investment, services, competition policy and government procurement, but was unable to say whether those benefits tend to be sufficient to offset any losses from trade diversion. Another recent review, by Nielsen (2003), came to similar conclusions, and added that the greatest gains for developing countries from FTAs would come if developed countries were to liberalize trade in their politically sensitive sectors, most notably agriculture but also textiles and clothing. That is likely in preferential agreements only with the smallest of developing countries whose impact on protective developed economies is tiny - examples of which are examined in the next sub-section.

\subsubsection{Removing developed country barriers to exports from least-developed countries}

The EU's recent initiative to extend preferences for United Nations-designated 'least developed countries' (LDCs) provides duty-and quota-free access to the EU for exports of 'everything but arms' (EBA). That initiative received in-principle, bestendeavors endorsement at the WTO Ministerial in Doha in November 2001, but without any specific timetable. Liberal though that proposal sounds, note that it does not include trade in services (of which the most important for LDCs would be movement of natural persons, that is, freedom for LDC laborers to work on temporary visas in the EU or other 
high-wage countries - see Winters et al. 2003). Also, a number of safeguard provisions are included in addition to the EU's normal anti-dumping measures. Furthermore, access to three politically sensitive agricultural markets, bananas, rice and sugar, would be phased in by the EU only gradually over the rest of this decade (and would be subject to stricter safeguards).

Several empirical studies of the proposal have already appeared. A World Bank study by Ianchovichina, Mattoo and Olarreaga (2001) compares the EU proposal, from the viewpoint of Sub-Saharan Africa (SSA), with recent initiatives of the United States and Japan. Its GTAP modeling results suggest that even the most generous interpretation of the United States' Africa Growth and Opportunity Act (which they model as unrestricted access to the US for all SSA exports) would benefit SSA very little because the US economy is already very open and, in the products where it is not (e.g. textiles and clothing), SSA countries have little comparative advantage. By contrast, the EU proposal, especially if it were to apply to all Quad countries (the EU, the US, Canada and Japan), would have a sizeable effect on SSA trade and welfare - provided agriculture is included in the deal. Just from EU access alone, SSA exports would be raised by more than US $\$ 0.5$ billion and SSA economic welfare would increase by $\$ 0.3$ billion per year (a 0.2 percent boost). ${ }^{19}$ The results overstate the benefits of the EU proposal, however, as this World Bank study assumes all SSA countries (excluding relatively wealthy South Africa and Mauritius), not just the LDCs amongst them, would get duty- and quota-free access.

Another World Bank study, by Hoekman, Ng and Olarreaga (2002), uses a partial equilibrium approach and looks at the benefit of the EU initiative for LCDs not just in SSA but globally. It finds that trade of LDCs would increase by US\$2.5 billion per year if all Quad countries provided LDCs with duty- and quota-free access on all merchandise. ${ }^{20}$ However, almost half of that increase would come as a result of trade diversion from other developing countries. The authors suggest this is trivial because it represents less than 0.1 percent of other developing countries' exports (about $\$ 1.1$ billion). ${ }^{21}$ But if the 48 LDCs are given such preferences, they will become advocates for rather than against the continuation of MFN tariff peaks for agriculture and textiles - diminishing considerably the number of WTO members negotiating for their reduction. It may be true that MFN reductions in agricultural and textile tariffs would help LDCs much less than it would help other developing countries, as the study by Hoekman et al. (2002) finds; but the gains to consumers in the QUAD would be more than sufficient to allow them to increase their aid to LDCs to compensate many times over for the loss of LDC income from the preference erosion that necessarily accompanies MFN reform.

\footnotetext{
${ }^{19}$ This is very similar to the estimate by UNCTAD/Commonwealth Secretariat (2001, Ch. 3).

${ }^{20}$ This and other estimates of gains from preferential market access provisions need to be discounted to the extent that such things as rules of origin, anti-dumping duties, and sanitary, phytosanitary and other technical barriers limit the actual trade allowed. For a detailed analysis of these types of restrictions on EU imports from Bangladesh in recent years, see UNCTAD/Commonwealth Secretariat (2001, Ch. 5).

${ }^{21}$ The impact outside the LDC group would be far from trivial for Mauritius, however, since the vast bulk of its exports are quota-restricted sales of clothing and sugar to the EU and US. See the discussion in UNCTAD/Commonwealth Secretariat (2001, Ch. 6).
} 


\subsubsection{How best to reduce subsidies and trade barriers globally by 2010?}

To open markets in the face of the political economy pressures for retaining subsidies and trade barriers requires seizing on not just one of the above-mentioned four opportunities but rather adopting a multi-pronged approach. That approach would seek to achieve unilateral reform at the national level and multilateral reform at the WTO level, supplemented by regional support for both as adopted by APEC members in what its supporters call open (that is, MFN) regionalism. Exploiting this set of opportunities requires developing stronger lobbies for freer MFN trade and investment, to counter the lobbying of entrenched protectionist forces. That in turn requires sponsoring policy think tanks and other suppliers of international trade policy analysis and advocacy, so that the vast majority of the community who would gain from freer trade are made more aware of the inefficiencies and inequities associated with subsidies and trade restrictions. Just one or two billion dollars per year over the next five years could go a long way in altering the climate of public opinion on this issue. The aim would be to encourage national governments to engage not only in unilateral reform but also to embrace the opportunity to negotiate an ambitious outcome from the WTO's current Doha Development round of multilateral trade negotiations. The latter is important because if other countries also agree to liberalize, that makes it easier for any one government to persuade its constituency to liberalize too; and if it is done within the WTO framework, those commitments will be MFN and they will be legally bound so that backsliding in the future becomes much less of an option. With the forces of globalization encouraging good (and penalizing bad) economic governance more than ever before, an ambitious target is appropriate. For the rest of this paper, the target is assumed to be a 50 percent reduction in subsidies and trade barriers as bound in the WTO (hence a smaller reduction in applied tariff rates, particularly for developing countries given the large degree of 'binding overhang' in their current WTO tariff commitments - see Francois and Martin 2003). ${ }^{22}$

Preferential trade agreements would not be included in this approach, even though they will no doubt continue to be pursued in the years ahead. Non-reciprocal trade preference agreements in particular are of questionable value, for at least five reasons which apply to the 'everything but arms' initiative discussed above and equally to the agreement the EU has had with its former colonies known collectively as ACP (Asia, Caribbean and Pacific) developing countries. First, many other equally poor but nonLDC/non-ACP developing countries (e.g., Vietnam) are harmed by such preferences. This was made abundantly clear in the 1990s during the infamous dispute-settlement case that was brought to the WTO concerning the EU's banana import regime. One background study showed that for every dollar of benefit that the banana policy brought to producers in ACP countries, the regime harmed non-ACP developing country

\footnotetext{
${ }^{22}$ This 50 percent across-the-board cut is in between two other possibilities: an ambitious Swiss formula which would cut higher tariffs by a larger percentage, and a conservative approach which at the extreme would exclude tariff peaks (as was effectively done in earlier GATT rounds in which agricultural and textile protection was not lowered). A study by Fontagné, Guérin and Jean (2004) uses a new and very detailed tariff data set to compare these three possible modalities. They find that the conservative approach (excluding cuts to tariff equivalents in excess of 15 percent for manufacturing and of 85 percent for agriculture) generates only half the welfare gains of the across-the-board approach, while the Swiss formula approach gave considerably larger gains, especially for those countries with the highest tariff peaks.
} 
producers by almost exactly one dollar - and in the process harmed EU consumers by more than thirteen dollars (Borrell 1999a). It is difficult to imagine a more inefficient way of transferring welfare to poor countries, since EU citizens could have been, through official development assistance payments, 13 times as effective in helping ACP banana producers and not hurt non-ACP banana producers at all. ${ }^{23}$ Such wasteful trade diversion is avoided under non-discriminatory, MFN liberalizations that result from multilateral trade negotiations under WTO.

Second, the additional production that is encouraged in those LDCs or ACP countries getting privileged access to the high-priced EU market is not internationally competitive at current prices (otherwise it would have been produced prior to getting that preferential treatment). Indeed the industry as a whole may not have existed in the LDC/ACP country had the preference scheme not been introduced. ${ }^{24}$ In that case, its profits are likely to be lean despite the scheme, and would disappear if and when the scheme is dismantled or EU MFN tariffs are reduced. Efforts to learn the skills needed, and the sunk capital invested in that industry rather than in ones in which the country has a natural comparative advantage, would then earn no further rewards.

Third, these preference schemes reduce very substantially the capacity for developing countries as a group to press for more access to developed country markets. Perhaps if such preferences had not been offered in the first place, developing countries would have negotiated much more vigorously in previous GATT rounds for lower tariffs on agricultural and other imports to developed countries.

Fourth, because these preferential access schemes are not reciprocal agreements (that is, the developing countries are not required to open their markets to developed countries' exports) they contribute nothing to the removal of the wasteful trade-restrictive policies of the LDC/ACP countries. This contrasts with market access negotiations under WTO, which are characterized by reciprocity.

Points one through three also apply to South-North reciprocal FTAs. Furthermore, the latter agreements are rarely just a simple sentence such as: there shall be free trade between the parties. On the contrary, they can run to thousands of pages involving long lists of exceptions, complex rules of origin and dispute settlement procedures, differing phase-in periods for different products, safeguard mechanisms, requirements to meet the trade partner's myriad standards, and so on. So complex are such features that it is not uncommon for firms to pay the MFN tariff rather than do all the paperwork necessary to get duty-free access within an FTA. And while they are potentially able to deliver gains to those who join them, FTAs do so to some extent at the expense of excluded countries and so, as was clear from the discussion in Section 4.1.4 above of the FTAA studies, they contribute only a small fraction of the gains that can come from WTO-based multilateral reform - and yet they can involve a major diversion of trade negotiator attention away from WTO negotiations. In any case, the more MFN tariffs are reduced the less need there is for preferential trade agreements.

\footnotetext{
${ }^{23}$ The EU is contemplating moving by 2006 to a tariff-only regime for banana imports from non-ACP countries, and in the process raising its tariff from the current 75 Euros. That could raise the protective effect of the tariff for ACP countries currently enjoying duty-free access, so yet again harming other developing countries (Borrell and Bauer 2004).

${ }^{24}$ Alternatively, the ACP scheme may have caused an existing industry to become less competitive. An extreme example of an industry that has ossified as a consequence of regulations introduced to share the expected benefits of EU preferences is sugar in Mauritius (Borrell 1999b).
} 
4.1.7 Summary of gross economic benefits from reducing subsidies and trade barriers by 2010

What can be concluded from the range of estimates in Table 3 of the gross economic benefits that would flow to developing countries and to the global economy as a whole from a halving of subsidies and trade barriers if that was agreed in 2004-05 and was phased in equally over five years from 2006? Some people will claim some of those estimates are too high for reasons that include the following:

- modelers should be cutting not applied but bound tariffs (as in the FMT study);

- increasing returns to scale should already have been exploited by producers so those modelers assuming IRS are exaggerating the gains from reform;

- the gains to developing countries enjoying tariff preferences in developed country markets are exaggerated if (as is the case) those preferential rates are not included in the models' tariff profiles; ${ }^{25}$

- domestic distortionary policies and exchange rate policies, which can inhibit the benefits of opening up, are not all included in the models;

- existing but currently redundant technical barriers might cease to be redundant and become binding constraints to trade as tariffs fall, in which case the rate of protection would fall less than the applied tariff rate; and

- re-instrumentation of assistance to industries will reduce the gains and may even turn them into losses if sufficiently inferior policy instruments (e.g., new technical barriers to trade) replace the ones being liberalized.

On the other hand, there are numerous reasons for believing some of the estimates in Table 3 may be too low, including the following:

- services as well as goods trade reforms need to be factored into the calculation, together with trade facilitation and FDI liberalization if not also international migration;

- the opening up of government procurement to foreign suppliers also needs to be modeled,

- non-agricultural subsidies (which are estimated to be around 60 percent of all direct government subsidies globally) are not modeled for removal in the reform scenarios;

- some of the productive factors initially absorbed to fuel reform-induced output growth, particularly unskilled labor, may have been previously underemployed;

- monopolistic competition and product variety/heterogeneity between firms needs to be modeled;

- price elasticities in the standard GTAP model arguably err on the low side;

- endogenous growth effects need to be included as a benefit;

${ }^{25}$ To the extent that the gains to preference-receiving developing countries are offset by losses to other countries because of trade diversion, the global welfare effects of accounting for preferences (given the smallness of recipient economies) will be very small. The GTAP Version 6.0 database is expected to include preferences when it is released in mid-2004, so future modelling studies should be able to account for this. 
- account needs to be taken of wasteful spending of resources on lobbying, as that will fall if assistance to industries (including re-instrumentation of existing protection) is announced to be a thing of the past;

- if trade reform encourages domestic policy and foreign exchange policy reforms as well, the benefits from those changes too need to be added; and, perhaps most important of all,

- the counterfactual to reform is not the status quo as assumed by modelers but increased protection, particularly for agriculture and conceivably also for other sectors without tariff bindings in place or for which technical barriers to trade or anti-dumping duties may then restrain trade.

With these claims and counter-claims it is not possible to be precise about the gross benefits that would result from any particular reform such as a halving of subsidies and trade barriers. A lower-bound estimate might be that provided in the IRS/MC part of the FMT study, which is the only study to consider cuts to bound (as distinct from applied) tariffs. That estimate amounts to 0.67 percent of GDP in 1997. It contrasts with the estimate from the BDS study, in which services trade liberalization includes dramatic growth in foreign direct investment. The latter's gain amounts to 3.0 percent of GDP in 2005. The HRTG study is between those two but only refers to goods trade reform. In the light of these estimates it is assumed in what follows that the comparative static gains from a 50 percent reform after full adjustment is an unweighted average of the BDS and FMT estimates, which is 1.8 percent of GDP for the world as a whole and 2.5 percent for developing countries (implying 1.6 percent for developed countries). And it is assumed that those gains will accrue fully after a five-year phase-in period, prior to which the gains will begin in 2006 at one-fifth the full amount as of 2010 and rise by a further onefifth each year until 2010.

There are dynamic gains from trade to consider in addition to those comparative static ones (not to mention the net benefits from non-farm subsidy cuts and the potentially massive gains from freeing up migration). The experiences of successful reformers such as Korea, China, India and Chile suggest trade opening immediately boosts GDP growth rates by several percentage points. To err on the conservative side, it is assumed here that reform boosts GDP growth rates - projected to 2015 by the World Bank (2003, Table A3.1) to be 2.7 percent for developed countries and 4.6 percent for developing countries - by one-sixth for developed countries and one-third for developing countries, that is, to 3.1 and 6.1 percent, respectively and hence from 3.2 to 3.8 percent globally. Those rates are assumed to continue to $2050 .^{26}$

To move from those gross effects to the net effects of these assumptions, it is necessary to consider the economic costs associated with reform, and also associated social and environmental benefits and costs.

\subsection{Economic costs of reducing subsidies and trade barriers}

The above benefits from reform are not costless of course. Expenditure on negotiating, and on supporting policy think tanks and the like to develop and disseminate a convincing case for reform, could be expanded many fold before running into declining

\footnotetext{
${ }^{26}$ It may be that the growth rate rises more than this initially and then fades in later decades, in which case the increase assumed can be considered the appropriately discounted average over that period.
} 
returns. But even if it did expand enormously, the increase globally would be trivial compared with the gains from reform (less than two billion dollars per year over the next five years).

Of much more significance are the private costs of adjustment for firms and workers as reform forces some industries to downsize or close to allow others to expand (Matusz and Tarr 2000; Francois 2003). Those costs are ignored in the full-employment CGE models discussed above.

There are also social costs to consider. They include social safety net provisions in so far as such schemes are developed/drawn on by losers from reform (e.g., unemployment payments plus training grants to build up new skills so displaced workers can earn the same wage as before), and perhaps increased costs of crime in so far as its incidence rises with transitional unemployment.

All three types are one-off costs to weigh against the non-stop flow of economic benefits from reform. The private and social costs of adjustment tend to be smaller, the longer the phase-in period or smaller the tariff or subsidy cut per year (Furusawa and Lai 1999). Also, CGE simulation studies suggest that the annual change in an industry's terms of trade due to phased trade reform is typically very minor relative to changes due to exchange rate fluctuations, technological improvements, preference shifts and other economic shocks and structural developments associated with normal economic growth (Anderson et al. 1997; Dixon et al. 2000).

Estimates of the magnitude of those costs are difficult to generate, but all available estimates suggest they are minor relative to the benefits from reform. An early study by Magee (1972) for the United States estimated the cost of job changes including temporary unemployment to be one-eighth of the benefits from tariff and quota elimination initially. Even assuming that transition took as many as five years, he estimated a benefit/cost ratio of 25 . A subsequent study which examined a 50 percent cut in US tariffs (but not quotas) came up with a similar benefit/cost estimate (Baldwin, Mutti and Richardson 1980). In more recent debates about trade and labor, analysts have had difficulty finding a strong link between import expansion and increased unemployment (see Greenaway and Nelson 2002). One example is a study of the four largest EU economies' imports from East Asia (Bentivogli and Pagano 1999). Another European example is a study of the UK footwear industry: liberalizing that market would incur unemployment costs only in the first year, because of the high job turnover in that industry, and those estimated costs are less than 1.5 percent of the benefits from cutting that protection (Winters and Takacs 1991). A similar-sized estimate is provided by de Melo and Tarr (1990) using a CGE model that focuses just on US textile, steel and auto protection cuts and drawing on estimates of the cost of earnings lost by displaced workers (later reported by Jacobson, LaLonde and Sullivan 1993). For developing countries also the evidence seems to suggest low costs of adjustment, not least because trade reform typically causes a growth spurt (Krueger 1983). In a study of 13 liberalization efforts for nine developing countries, Michaely et al. (1991) found only one example where employment was not higher within a year. A similar study for Mauritius by Milner and Wright (1998) also found trade opening to be associated with employment growth rather than decline. ${ }^{27}$

\footnotetext{
${ }^{27}$ A further impact of trade policy reform about which concern is often expressed is the loss of tariff revenue for the government. This is of trivial importance to developed and upper middle-income countries
} 
If the adjustment costs are so small and may lead to more rather than less jobs even during the adjustment period, why are governments so reluctant to open their economies? The reason is because the losses in jobs and asset values are very obvious and concentrated whereas the gains in terms of new job and investment opportunities are thinly spread, are less-easily attributed to the trade reform, and are taken up often by people other than those losing from the reform. ${ }^{28}$ As discussed in Section 2.3 above, the few losers are prepared to support politicians who resist protection cuts, while the gains are sufficiently small per consumer and unassisted firm as to make it not worthwhile for those many potential gainers to get together to lobby for reform, particularly given their greater free-rider problem in acting collectively (Olsen 1965). Hence the need for publicly funded trade policy think-tanks and the like to play an advocacy role.

A prime example of the role analysis can play has to do with effects on developing countries in reforms to support for agriculture in OECD economies. The primary channel for such effects is through the terms of trade, which in turn depend in part on whether a country is a net exporter or importer of the affected OECD products. Long-term support for agriculture in OECD countries, coupled with often-negative assistance to farmers in many developing countries, has left developing countries as a group dependent on imports of these subsidized products. As a result, an across-the-board cut in all domestic support for OECD agriculture leads to welfare losses for many developing countries and to declines in farm incomes in Europe, Japan and North America. Such a reform package is therefore unlikely to be implemented on its own. An alternative approach is to focus on broad-based reductions in market price support, as has begun occurring in the EU where domestic support has increasingly replaced border measures. As Dimaranan, Hertel and Keeney (2003) show, a shift from market price support to land-based payments could generate a win-win-win outcome whereby OECD

where trade taxes account for only 1 and 3 percent of government revenue, respectively. For lower middleincome countries that share is 9 percent, and it is more than 20 percent for more than a dozen low-income countries for which data are available, so how concerned should those poorer countries be? The answer depends on whether/how much that revenue would fall and, if it does fall, on whether/how much more costly would be the next best alternative means of raising government revenue. On the first of those two points, government revenue from import taxes will rise rather than fall with reform if the reform involves replacing, with less-prohibitive tariffs, any of import quotas or bans, or tariffs that are prohibitive (or nearly so) or which encourage smuggling or under-invoicing or corruption by customs officials. It is possible even in a tariff-only regime that lower tariffs lead to a sufficiently higher volume and value of trade that the aggregate tariff collection rises. Examples of recent trade policy reforms that led to increased tariff revenue are Chile and Mexico (Bacchetta and Jansen 2003, p. 15). See also Greenaway and Milner (1993) and Nash and Takacs (1998). Since the economy is enlarged by opening up, income and consumption tax collections will automatically rise too. On the second point, about the cost of raising government revenue by other means if tax revenue does fall, Corden (1997, Ch. 4) makes it clear that in all but the poorest of countries it will be more rather than less efficient to collect tax revenue in other ways. Even countries as poor as Cambodia have managed to introduce a value added tax. Hence from a global viewpoint there is no significant cost that needs to be included in response to this concern. To the extent subsidies are also cut as part of the reform, the chances of government revenue rising are even greater. Income and consumption tax revenue also will rise as the economy expands following reform. In any case CGE modellers typically alter those other tax rates when trade tax revenues change so as to keep the overall government budget unchanged.

${ }^{28}$ In the Australian context of high unemployment in the latter 1970s, Max Corden was prompted to write a deliberately non-technical paper called 'Tell us where the new jobs will come from?' because he knew the answer was not obvious to non-economists (Corden 1979). The paper proved so popular that thousands of offprints were distributed and in 1985 it was reprinted in The World Economy. 
farm incomes are maintained and yet world price distortions are reduced and economic welfare rises for most developing countries and globally. Provided these increased domestic support payments are not linked to output or variable inputs, the trade-distorting and welfare-reducing effects are likely to be small, thereby providing an effective way of offsetting the potential losses that would otherwise be sustained by OECD farmers. This type of policy re-instrumentation increases the probability that such reforms are politically acceptable in the reforming economies while simultaneously increasing the likelihood that they will be beneficial to developing countries. That analysis suggests developing country governments should focus their efforts on improved access to OECD food markets while permitting wealthy countries to increase their decoupled domestic payments as import tariffs are lowered.

So as not to exaggerate the net gains from trade reform, it is assumed here that there would be an adjustment period as long as five years following a 50 percent acrossthe-board liberalization, and that in each of those years the adjustment costs would be as much as 30 percent of the annual comparative static benefits as of 2010 (and zero thereafter). That amounts to $\$ 219$ billion per year during 2006 to 2010 globally, of which $\$ 64$ billion is expended in developing countries, when expressed in 2002 US dollars by using the projection to 2010 of global GDP provided by the World Bank (2003, Table A3.1).

A 100 percent ( 25 percent) liberalization would yield roughly twice (half) the gross benefits as a 50 percent liberalization but would have a much lower (higher) probability of being politically acceptable. This is because adjustment costs would be proportionately greater (less) with the bigger (smaller) reform. For the purposes of comparison, it is assumed here that a 100 (25) percent liberalization would involve adjustment costs equal to 40 (25) percent of the annual comparative static benefits as of 2010 and zero thereafter, instead of the 30 percent assumed for a halving of subsidies and trade barriers.

\subsection{Social and environmental benefits and costs of reducing subsidies and trade barriers}

Because trade reform generates large and on-going economic gains while incurring comparatively minor one-off adjustment costs, it would allow individuals and governments to spend more on other pressing problems, thereby indirectly contributing to the alleviation of other challenges facing society. But in addition, trade reform would also directly alleviate some of those challenges. This section first focuses on the impact of trade reform on poverty alleviation, since that is the solution to many of the world's problems. It then turns to trade reform's impact on the environment, before briefly commenting on its impact on several of the other specific challenges being addressed in this project, namely climate change, communicable diseases, conflicts, education underinvestment, financial instability, poor governance and corruption, population and migration issues and under-nutrition and hunger. 


\subsubsection{Poverty alleviation}

Evidence presented by Dollar and Kraay (2002) and Sala-i-Martin (2002) among others suggests aggregate economic growth differences have been largely responsible for the differences in poverty alleviation across regions. Initiatives that boost economic growth are therefore likely to be helpful in the fight against poverty, and trade liberalization is such an initiative. But cuts to subsidies and trade barriers also alter relative product prices domestically and in international markets, which in turn affect factor prices. Hence the net effect on poverty depends also on the way those price changes affect poor households' expenditure and their earnings net of remittances. If the consumer and producer price changes (whether due to own-country reforms and/or those of other countries) are pro-poor, then they will tend to reinforce any positive growth effects of trade reform on the poor.

The effects of trade reform on global poverty can be thought of at two levels: on the income gap between developed and developing countries, and on poor households within developing countries. On the first, the CGE estimates surveyed above suggest that current developing countries, which produced just 19 percent of global GDP in 2002, would enjoy nearly half of the net present value of the global static plus dynamic gains to 2050 from halving trade barriers (see Section 4.4 below). Clearly that will reduce substantially the income gap between developed and poorer countries on average.

How poor households within developing countries are affected is more difficult to say (Winters 2002; McCulloch, Winters and Cirera 2001). What is clear from Table 2 is that the agricultural policies of developed countries provide a major source of developing country gains from reform, and lowering barriers to textiles and clothing trade also is important. Both would boost the demand for unskilled labor and for farm products produced in poor countries. Since two-thirds of the world's poor live in rural areas and, in least-developed countries, the proportion is as high as 90 percent (OECD 2003a, p. 3), and since most poor rural households are net sellers of farm labor and/or food, one would expect such reforms to reduce the number in absolute poverty (Anderson 2004; Cline 2004a). ${ }^{29}$ A preliminary analysis by Hertel, Ivanic, Perckel and Cranfield (2003), in which GTAP results are carefully combined with household income and expenditure survey data for 14 developing countries, tests this hypothesis and finds strong support for it in most of the 14 cases considered.

\subsubsection{The environment}

The effects of trade reform on the environment have been the focus of much theoretical and empirical analysis since the 1970s and especially in the past dozen or so years (Copland and Taylor 2003; Beghin et al. 2002). Until recently environmentalists have tended to focus mainly on the direct environmental costs they perceive from trade reform, just as they have with other areas of economic change. ${ }^{30}$ That approach does not acknowledge areas where the environment might have been improved, albeit indirectly, as a result of trade reform (e.g., from less production by pollutive industries that were

\footnotetext{
${ }^{29}$ Das (2001) describes independent India's lack of openness prior to the 1990s as 'a great betrayal' that kept hundreds of millions of people in poverty for two generations longer than necessary.

${ }^{30}$ See the critique by Lomborg (2001).
} 
previously protected). Nor does it weigh the costs of any net worsening of the environment against the economic benefits of policy reform of the sort described above.

The reality is that while the environmental effects of reform will differ across sectors and regions of the world, some positive and some negative, there are many examples where cuts to subsidies and trade barriers would reduce environmental damage (Anderson 1992; Irwin 2002, pp. 48-54). For some time the OECD has been encouraging analysis of these opportunities (OECD 1996, 1997, 1998, 2003b). Environmental NGOs are increasingly recognizing them, with Greenpeace currently focusing on energy subsidies, WWF on fisheries subsidies (WWF 2001), and IISD and Friends of the Earth on subsidy reforms generally (e.g., Myers and Kent 1998; FOE et al. 2003). They and the better-informed development NGOs such as Oxfam seem to be coming to the view that the net social and environmental benefits from reducing subsidies and at least some trade barriers may indeed be positive rather than negative, and that the best hope of reducing environmentally harmful subsidies and trade barriers is via the WTO's multi-issue, multilateral trade negotiations process.

If there remains a concern that the net effect of trade reform on the environment may be negative nationally or globally, that should be a stimulus to check whether firstbest environmental policy measures are in place and set at the optimal level of intervention, rather than a reason for not reducing trade distortions. This is because if they are so set, we would then know that the direct economic gains from opening to trade would exceed society's evaluation of any extra environmental damage, other things equal (Corden 1997, Ch. 13).

Much environmental damage in developing countries is a direct consequence of poverty (e.g., the slash-and-burn shifting agriculture of landless unemployed squatters). In so far as trade reform reduces poverty, so it will reduce such damage. More generally, the relationships between per capita income and a wide range of environmental indicators have been studied extensively. Because richer people have a greater ability to demand a clean environment, income rises tend to be associated with better environmental outcomes once incomes rise above certain levels. ${ }^{31}$ Even though more pollutive products are being consumed as incomes rise, many abatement practices have been spreading fast enough to more than compensate. And openness to trade accelerates that spread of abatement ideas and technologies, making their implementation in developing countries affordable at ever-earlier stages of development.

Estimating the global cost to society of all environmental damage that might accompany a reduction in subsidies and trade barriers, net of all environmental gains, is extraordinarily difficult both conceptually and empirically. ${ }^{32}$ In the absence of any

\footnotetext{
${ }^{31}$ This is the theme of the recent book by Hollander (2003). For statistical evidence of the extent to which different environmental indicators first worsen and then improve as incomes rise (sometimes called the environmental Kuznets curve), see the special issue of the journal Environment and Development Economics, Volume 2, Issue 4 in 1997 and the more-recent papers by and cited in Harbaugh, Levinson and Wilson (2002) and Cole (2003).

${ }^{32}$ A beginning nonetheless is being made, with several governments funding ex ante evaluations of the WTO Doha round's potential impact on the environment. The EU's efforts include a workshop on methodological issues which are laid out in CEPII (2003), and further work has been contracted to the University of Manchester whose progress can be traced at http://idpm.man.ac.uk/siatrade/Consultation.htm. Ex post analyses are also being undertaken by NGOs. See, for example, Bermudez (2004) for WWF's sustainability impact assessment of trade policies during 2001-03.
} 
sufficiently comprehensive estimates it will be assumed that the net effect of reform on the environment would be zero.

\subsubsection{Climate change}

When the environmental impact is global rather than local, as with greenhouse gases and their alleged impact on climate change, international environmental agreements may be required (see Cline 2004b). When developing countries are not party to such agreements, however, it is difficult to prevent 'leakage' through a re-location of carbonintensive activities to those non-signatories. An alternative or supplementary approach that is likely to achieve at least some emission reductions, and at the same time generate national and global economic benefits rather than costs, involves lowering coal subsidies and trade barriers. Past coal policies have encouraged excessive production of coal in a number of industrial countries and excessive coal consumption in numerous developing countries including transition economies. Phasing out those distortionary policies has both improved the economy and lowered greenhouse gas emissions globally - a "no regrets' outcome or win-win Pareto improvement for the economy and the environment (Anderson and McKibbin 2000). Additional opportunities for reducing greenhouse gases through cutting energy subsidies are pointed to in the new UNEP study by von Moltke, McKee and Morgan (2004).

\subsubsection{Communicable diseases}

Communicable diseases are more common among the poor, so again trade reform's contribution to poverty alleviation will in turn impact on human health in general and the reduced incidence of diseases in particular. Furthermore, the greater openness of economies ensures medicines and prevention technologies are more widespread and cheaper, particularly following the Doha WTO conference of trade ministers and the subsequent Decision of 30 August 2003 on the TRIPS Agreement and Public Health. That Decision by the WTO General Council ensures developing country governments can issue compulsory licenses to allow other companies to make a patented product or use a patented process under license without the consent of the patent owner, while developing countries unable to produce pharmaceuticals domestically can now import generic copies of patented drugs made under compulsory licensing by other developing countries.

\subsubsection{Conflicts}

Openness tends to break down the common prejudices that accompany insularity, and to broaden mutual understanding between people with different cultures and customs. It also expands economic interdependence among countries, which raises the opportunity cost of entering into conflicts with trading partners. In so far as it reduces income inequality across countries, then that too diffuses tension between nations - a point that has even greater significance following the terrorist attacks of 11 September 2001. Indeed there is now statistical support for Immanuel Kant's hypothesis that durable peace is supported by representative democracy, trade, and membership of international 
organizations: Oneal and Russett (2000) find that all three contribute independently to more peaceful relationships with other countries. ${ }^{33}$ And casual observation suggests that more-autarchic economies tend to be less democratic.

Where openness involves also greater international migration, there tends to be less inter-cultural conflict and more social gains from multiculturalism. Conversely, it is in societies that resent immigrants and impose strict migration quotas where cultural clashes seem to be more common. Clashes between ethnic groups are also more common where a minority prospers greatly relative to the majority or other significant minorities (Chua 2003). Such income and wealth inequality within a country tends to be less common the more open is the economy, at least after the initial adjustments to reform (Williamson 2002).

\subsubsection{Education under-investment}

Parents and governments are less likely to under-invest in education the higher their incomes, other things equal. So to the extent that trade reform raises incomes, it contributes to better educational outcomes. That is especially so for the very poorest who cannot afford even primary education: a slight increase in the cash income of poor farm families, for example following a reform-induced increase in international prices of farm products, can make it possible to pay the (often relatively high) school fees that are otherwise unaffordable.

\subsubsection{Financial instability}

Trade reform 'thickens' international markets by raising the share of global production that passes through them. That typically reduces the variation across time in prices for traded products. It also expands the demand for international financial services to transfer the required payments and often to provide temporary credit. Together these forces contribute to the long-term stability of financial markets.

Openness also tends to reduce inflation. It can do so by increasing competition in domestic markets, which drives down prices and reduces political pressure on the central bank to inflate, and by providing more options for people to hold savings in foreign currencies, which reduces the ability of governments to inflate savings away (Rogoff 2003).

\subsubsection{Poor governance and corruption}

A tolerance for subsidies and trade barriers breeds rent-seeking by special interests seeking protectionist policies for their industry. If those policies include import licensing, that breeds corruption through encouraging bureaucrats responsible for allocating licenses to accept bribes from would-be importers. Together those activities ensure that the welfare costs of trade barriers are higher than is typically measured, since a share of the private rents they generate are wasted in these lobbying activities. Tax-

\footnotetext{
${ }^{33}$ A recent survey of the evidence did not find a significant direct link between poverty and terrorism, however. Rather, Krueger and Maleckova (2002) concluded that terrorism was more a response to political conditions and long-standing feelings of indignity and frustration.
} 
avoiding corruption is also encouraged in the case of import tariffs, for example through bribing customs officers or through smuggling. For these reasons it is not surprising that statistical analysis has found less-open economies to be more corrupt (Ades and Di Tella 1999).

\subsubsection{Population and migration issues}

The challenge in developed countries of a shortage of low-skilled workers has been eased by merchandise trade with and FDI flows to labor-abundant developing countries, most notably China in the past two decades. But that has been far from sufficient to equalize wages across countries. Historical experience in the 50 years to World War I showed that by far the fastest way to bring about a convergence in living standards is through international migration (Williamson 2002). Notwithstanding the liberalization of much merchandise trade post-World War II, and the opportunity through the WTO's Doha round to reduce those and services trade barriers further, the CGE analyses by Hamilton and Whalley (1984) and Winters et al. (2003) suggest that this will still be the case in the foreseeable future. When coupled with an aging population in developed countries, there is a compelling case for them to expand their quotas on immigrants from developing countries. Indeed Mattoo and Subramanian (2003) argue that this would be essential if the Doha round is to deliver on its promise of being development-friendly.

\subsubsection{Under-nutrition and hunger}

Food security is always a great concern in poor countries, especially those dependent on food imports where there are fears that reducing agricultural subsidies and protectionism globally will raise the price of those imports. But food security is defined as always having access to the minimum supply of basic food necessary for survival, so enhancing food security is mainly about alleviating poverty. That suggests this issue needs to be considered from a household rather than national perspective. ${ }^{34}$ If an international food price rise from trade reform abroad is transmitted domestically, the vast majority of the poor in low-income countries would benefit directly. This is because the poor are found predominantly in farm households and are net sellers of food. Even poor landless farm laborers who are net buyers of food would benefit indirectly from an agricultural price rise via a rise in the demand for their unskilled farm labor if that raises

\footnotetext{
${ }^{34}$ Even from a national viewpoint, it is not necessarily the case that a country that is currently a net food importer will lose from a rise in the international price of food. If, for example, it is close to self-sufficient in food without price supports, and reform abroad raises the international price of food, it may switch to become sufficiently export-oriented that its net national economic welfare rises. A second possibility is that a developing country's own policies are sufficiently biased against food production that the country is a net importer, despite having a comparative advantage in food. In that case, it has been shown that the international price rise can improve national economic welfare, even if the price change is not sufficient to turn that distorted economy into a net food exporter (Anderson and Tyers 1993). That comes about because the higher price of food attracts mobile resources away from more-distorted sectors, thereby improving the efficiency of national resource allocation. Because of these two possibilities, the number of poor countries for whom a rise in international food prices might cause some hardship is much smaller than the number that are currently net importers of food products.
} 
their wage enough to more than offset the rise in food prices in rural areas. The earnings prospects for other landless rural poor will have risen too, along with the demand for labor in local enterprises that grow as farmers spend their enhanced income on simple manufactures and services produced nearby. Since the typically more affluent people in cities would find it relatively easy to pay a little extra for food, the only other major vulnerable group is the under-employed urban poor. But even that group may not be worse off in so far as trade reform generates a more-than-offsetting increase in the demand for that group's unskilled labor, which is used relatively intensively in (often informal sector) services or, if developed countries were to reduce also their barriers to imports of textiles and clothing, the apparel industry.

What about in developing countries where multilateral agricultural trade liberalization means lower domestic prices for agricultural products because such countries had kept domestic food prices above international levels via import restrictions? It is true that removing those distortions will reduce farm incomes in those countries (but by more for larger than smaller farms), and urban households will benefit from lower food prices. However, food self-sufficiency will fall - and it is the fall in both farm earnings and food self-sufficiency that focuses the attention of those who argue that agricultural trade liberalization is bad for poor households. Focusing on just the direct effects of agricultural trade policy reform can be misleading, however, not least because it does not take account of the fact that such reform would be undertaken in the context of multilateral, economy-wide liberalization. Being multilateral means that other countries' farm protection cuts raise international food prices, and so less of a price fall occurs than when a country cuts its agricultural protection unilaterally. And being economy-wide means the decline in demand for farm labor is more or less offset by a growth in demand for labor in expanding non-farm industries such as apparel. ${ }^{35}$

Hunger and under-nutrition can be eased by trade not only in goods but also in agricultural technologies, in particular newly bred varieties of staple crops (Runge et al. 2003). The introduction of high-yielding dwarf wheat and rice varieties during the Green Revolution that began in Asia in the 1960s is a previous case in point, whereby producers and consumers shared the benefits in terms of higher farm profits and lower consumer prices for cereals. A prospective case in point is the possibility of breeding crop varieties that are not only less-costly to grow but are 'nutriceuticals' in the sense they contain vitamin and mineral supplements. The most promising is so-called 'golden rice'. Consumers in many of poor countries suffer from chronic vitamin A deficiency that can lead to blindness, weakened immune systems, and increased morbidity and mortality for children and pregnant and lactating women. Golden rice has been genetically engineered to contain a higher level of beta-carotene in the endosperm of the grain and thereby provide a vitamin A supplement. By being cheaper and/or more nutritionally beneficial, it would improve the health of poor people and thereby also boost their labor productivity. Anderson, Jackson and Nielsen (2004) estimate that the latter economic benefit from this

\footnotetext{
${ }^{35}$ These expectations are supported by the recent household-focused CGE analysis by Hertel, Ivanic, Preckel and Cranfield (2003). An interesting exception, though, is Mexico: poverty there has been reduced by Mexico's preferential access into the US market via NAFTA, and the benefit of those preferences would decrease with multilateral reform because Mexico would then have to share some of those earlier gains with other developing countries. This result highlights the beggar-thy-neighbour nature of FTAs, as discussed above in Section 4.1.5.
} 
new technology could be as much as 10 times greater than just the traditional benefits of lower production costs - not to mention that poor people would live longer and healthier lives. This new technology has yet to be adopted, however, because the European Union and some other countries will not import grain from countries that produce food that may contain genetically modified organisms (GMOs) - even though there is no evidence that GM foods are a danger to human health (see, e.g., King 2003). That trade barrier may be challenged at the WTO because it is seen by adopters of GM corn and soybean simply as a disguised form of economic protection for European farmers (an hypothesis that is not inconsistent with empirical research showing that the EU's moratorium on GM food boosts EU farm household incomes even though it denies them the opportunity to adopt the new technology - see Anderson and Jackson 2004).

\subsection{Global net present value and benefit/cost ratio from lowering subsidies and trade barriers by 2010}

The previous section points to numerous examples of net social benefits from trade liberalization, but is unable to quantify them let alone all the other social and environmental benefits and costs of such policy reform. For present purposes of estimating the net present value of this opportunity to reduce subsidies and trade barriers, they will therefore be ignored even though, like the net gains from migration, they are most likely positive and large.

With that in mind, lower-bound estimates of the overall net benefits from halving subsidies and trade barriers are calculated as the differences each year between the economic benefits and costs discussed in Sections 4.1 and 4.2 above. As shown in Figure 1 , these benefits would roughly double the annual increment to global GDP after the initial adjustment period. Even if the benefits ceased after 50 years, their net present value in 2005 at a discount rate of 5 percent would be $\$ 23,040$ billion for the world economy, of which $\$ 11,500$ billion or almost half would accrue to the current developing countries (expressed in 2002 US dollars, when global and developing country GDPs were $\$ 32,016$ and $\$ 6,079$ billion, respectively). That implies a benefit/cost ratio of 24.3 globally and 37.9 for developing countries. If the dynamic gains (in addition to prospective migration gains and social and environmental net benefits) are ignored, the global gains are $\$ 17,100$ billion in terms of net present value, implying a benefit/cost ratio of 18.1 for the world as a whole. Table 4 summarizes these results as the Optimistic Doha opportunity. For comparison it also shows the benefit/cost ratios for a 100 percent liberalization and for a Pessimistic Doha outcome of a 25 percent liberalization, assuming proportionately higher (lower) costs of adjustment when the reform is greater (smaller) as discussed in Section 4.2 above.

Even if one believes the probability of a successful Doha round is low, that it might take some years beyond 2005 to complete and beyond 2010 before its full impact is felt, that it might involve much less than a halving of subsidies and trade barriers, that the comparative static gains are closer to the lowest estimate in Table 3, and that the dynamic gains would boost GDP growth rates by less than one-sixth for developed countries and one-third for developing countries, the alternative net present value estimates one would generate are likely still to be enormous - both absolutely and relative to the cost associated with this reform. And that benefit would be even larger if 
the counterfactual was not the status quo but a rise in protectionism and a decline in the WTO institution and the rules-based global trading system it supports.

The estimated net benefit to developing countries after adjusting to greater access to developed country markets is large compared with official development assistance currently provided by OECD countries to developing countries (around $\$ 60$ billion per year). It is large also compared with the foreign direct investment (FDI) funds that flow from OECD to developing countries (between $\$ 120$ and $\$ 150$ billion per year). Yet it would not be costly for developed countries to provide that greater market access. On the contrary, those countries would gain even more in dollar terms than developing countries from such policy reform (see Table 2), giving them extra resources to expand their development assistance and FDI and thereby to further reduce global income inequality and poverty (particularly if non-farm subsidies also were cut). All that is required is bold leadership to grasp the opportunities before us for unilateral and multilateral trade reform and associated subsidy cuts, particularly via the WTO's Doha round of negotiations. 


\section{Conclusion}

The theory and available evidence surveyed above show that subsidies and trade barriers are not only economically wasteful but many also have harmful social and environmental effects. Even where the latter effects are not harmful, there are almost always cheaper ways of obtaining those social and environmental effects than via trade and subsidy measures. The reasons these inefficient measures persist is partly lack of understanding of the benefits being foregone, but mostly it is because a small number of vested interests lobby for their retention. The challenge is to find politically feasible opportunities for ridding the world of subsidies and trade barriers. This paper suggests the most obvious way is currently before us in the form of the Doha Development Agenda of multilateral trade negotiations under the World Trade Organization. Seizing that opportunity for reform could reduce government outlays by hundreds of millions of dollars. It could also allow citizens to spend more on other pressing problems (because under freer trade the world's resources would be allocated more efficiently), thereby indirectly contributing to opportunities to alleviate other challenges facing the world; and it could also directly alleviate poverty and thereby reduce environmental degradation and address other challenges such as communicable diseases, conflicts and arms proliferation, education under-investment, corruption, migration issues, water issues, and undernutrition and hunger. 


\section{Appendix: The global, economy-wide GTAP database and model}

To estimate the potential economy-wide effects of regional and multilateral trade liberalizations, by far the most common methodology since the 1980s has involved a global computable general equilibrium (CGE) model and database. ${ }^{36}$ It is a daunting task to compile and periodically update all the necessary data for such a model so, under the direction of Professor Tom Hertel of Purdue University, a consortium was established more than a decade ago for this purpose. Known as GTAP (the Global Trade Analysis Project), it is currently providing Version 5 of its database, with Version 6 to be released in the spring of 2004. That latest database provides reconciled production, consumption and bilateral goods and services trade data plus subsidies and trade distortion estimates ${ }^{37}$ (including developing country preferences) as of 2001 for 78 countries or country groups spanning the world, each divided into 57 sectors spanning the entire economy (see www.gtap.org). Earlier versions based on 1997 or 1995 data had less country and product disaggregation and did not include tariff preferences. This database is the foundation of most global CGE trade models in use today. The current version is described in detail in Dimaranan and McDougall (2002).

In addition, the GTAP Center at Purdue University has developed its own family of applied general equilibrium models (Hertel 1997). The core GTAP model is a standard, multiregion CGE model that is currently being used by several hundred researchers in scores of countries on five continents. (The GTAP database builds on contributions from many of these individuals, as well as the national and international agencies in the GTAP Consortium.) Perfect competition and constant returns to scale are assumed for all sectors of each economy in the core comparative static version.

The GTAP model utilizes a sophisticated representation of consumer demands that allows for differences in both the price and income responsiveness of demand in different regions depending upon both the level of development of the region and the particular consumption patterns observed in that region. On the supply-side, differences in factor endowments within and between countries interact with different sectoral factor intensities to drive changes in the sectoral composition of output in response to structural or policy shocks. The GTAP production system distinguishes sectors by their intensities in five primary factors of production: agricultural land, other natural resources, unskilled labor time, skilled labor time, and physical capital. Thus in a region where physical capital is accumulating rapidly relative to other factors, for example, that region's relatively capital intensive sectors tend to expand at the expense of other sectors. In addition to differences in intermediate input intensities, import intensities are also permitted to vary across uses. Since much trade is in intermediate inputs, the distinction between sales to final consumers and sales to other firms can be important. Lowering the cost of imported goods to consumers is quite different from lowering the cost of intermediate inputs to domestic firms that may be competing with imports in the final product market. As well, products are differentiated by place of production. The linkage between the different prices of a product is typically quite strong, but will depend on the degree of substitutability in consumption. In addition to matching up more effectively with reality, this approach has the advantage of permitting bilateral trade to be tracked, as opposed to simply reporting total exports net of imports.

\footnotetext{
${ }^{36}$ On the need for adopting a general rather than partial equilibrium methodology, see Anderson (2002).

${ }^{37}$ Estimating the height of trade barriers is a non-trivial task in itself, even for merchandise (Evans 2003) but especially for services (Findlay and Warren 2001) and if technical barriers to trade are involved (Maskus and Wilson 2001).
} 


\section{References}

Adams, R., P. Dee, J. Gali and G. McGuire (2003), 'The Trade and Investment Effects of Preferential Trading Arrangements: Old and New Evidence,' Staff Working Paper, Canberra: Productivity Commission, May.

Ades, A. and R. di Tella (1999), 'Rents, Competition, and Corruption,' American Economic Review 89 (4): 982-93, September.

Anderson, K. (1992), 'Effects on the Environment and Welfare of Liberalising World Trade: The Cases of Coal and Food,' Ch. 8 in The Greening of World Trade Issues, edited by K. Anderson and R. Blackhurst, London: Harvester-Wheatsheaf and Ann Arbor: University of Michigan

Anderson, K. (2002), 'Economy-wide Dimensions of Trade Policy Reform,' Ch. 2 in Development, Trade and the WTO: A Handbook, edited by B. Hoekman, A. Matoo and P. English, Washington, D.C.: The World Bank.

Anderson, K. (2003), 'Measuring Effects of Trade Policy Distortions: How Far Have We Come?' The World Economy 26(4): 413-40, April.

Anderson, K. (2004), 'Agricultural Trade Reform and Poverty Reduction in Developing Countries,' in International Trade and Development: Essays in Honour of Peter Lloyd, edited by S. Jayasuriya and P.J. Lloyd, London: Edward Elgar (forthcoming).

Anderson, K., B. Dimaranan, J. Francois, T. Hertel, B. Hoekman and W. Martin (2002), 'The Burden of Rich (and Poor) Country Protectionism on Developing Countries,' Journal of African Economies 10(3): 227-57, September.

Anderson, K., B. Dimaranan, T. Hertel and W. Martin (1997), 'Economic Growth and Policy Reforms in the APEC Region: Trade and Welfare Implications by 2005', Asia-Pacific Economic Review 3(1): 1-18, April.

Anderson, K. and L.A. Jackson (2004), 'Standards, Trade and Protection: The Case of GMOs', paper presented at the Annual Conference of the American Agricultural Economics Association, Denver CO, 1-4 August.

Anderson, K., L.A. Jackson and C.P. Nielsen (2004), 'Who Would Benefit from the Adoption of Golden Rice in Asia?' paper presented at the $7^{\text {th }}$ Annual Global Economic Analysis Conference, Washington DC, 19-19 June.

Anderson, K. and W. McKibbin (2000), 'Reducing Coal Subsidies and Trade Barriers: Their Contribution to Greenhouse Gas Abatement,' Environment and Development Economics 5(4): 457-81, October.

Anderson, K. and R. Tyers (1993), 'More on Welfare Gains to Developing Countries from Liberalising World Food Trade,' Journal of Agricultural Economics 44(2): 189-204, May.

Anson, J., O. Cadot, J. de Melo, A. Estevadeordal, A. Suwa Eisenmann and B. Tumurchudur (2003), 'Rules of Origin in North-South Preferential Trading Arrangements with an Application to NAFTA,' CEPR Discussion Paper No. 4166, London, December.

Bacchetta, M. and M. Jansen (2003), 'Adjusting to Trade Liberalization: The Role of Policy, Institutions and WTO Disciplines,' Special Studies 7, Geneva: World Trade Organization, April. 
Bagwell, K. and R.W. Staiger (2004), 'Subsidy Agreements', NBER Working Paper 10292, Cambridge MA, February.

Baldwin, R.E. (2004), 'Openness and Growth: What's the Empirical Relationship?' in Challenges to Globalization: Analysing the Economics, edited by R.E. Baldwin and L.A. Winters, Chicago: University of Chicago Press for NBER and CEPR (forthcoming).

Baldwin, R.E., J. Mutti and J.D. Richardson (1980), 'Welfare Effects on the United States of a Significant Multilateral Trade Reduction', Journal of International Economics 6: 405-23.

Baldwin, R., R. Forslid, P. Martin, G.M. Ottaviano and F. Robert-Nicoud (2003), Economic Geography and Public Policy, Princeton NJ: Princeton University Press.

Bandara, J. and W. Yu (2003), 'How Desirable is the South Asian Free Trade Area? A Quantitative Economic Assessment', The World Economy 26(9): 1293-1324, September.

Beers, C. van and A. de Moor (2001), Public Subsidies and Policy Failures: How Subsidies Distort the Natural Environment, Equity and Trade and How to Reform Them, Cheltenham: Edward Elgar.

Beghin, J., D. van der Mensbrugghe and D. Roland-Holst (2002), Trade and the Environment in General Equilibrium: Evidence from Developing Economies, Norwell MA: Kluwer Academic Publishers.

Bendivogli, C. and P. Pagano (1999), 'Trade, Job Destruction and Job Creation in European Manufacturing', Open Economies Review 10: 156-84.

Bermudez, E. (2004), Sustainability Assessments of Trade Policies and Programmes, Gland: WWF International, January.

Bhagwati, J.N. (1971), 'The Generalized Theory of Distortions and Welfare', in Trade, Balance of Payments and Growth, edited by J.N. Bhagwati et al, Amsterdam: North-Holland.

Bhagwati, J.N. (1988), Protectionism, Cambridge MA: MIT Press.

Bhagwati, J.N. and R. Hudec (eds.) (1996), Fair Trade and Harmonization, Cambridge MA: MIT Press.

Borrell, B. (1999a), 'Bananas: Straightening Out Bent Ideas on Trade as Aid', Paper presented at the World Bank/WTO Conference on Agriculture and the New Trade Agenda from a Development Perspective, Geneva, 1-2 October.

Borrell, B. (1999b), 'Sugar: The Taste Test of Trade Liberalization', Paper presented at the World Bank/WTO Conference on Agriculture and the New Trade Agenda from a Development Perspective, Geneva, 1-2 October.

Borrell, B. and M. Bauer (2004), 'EU Banana Drama: Not Over Yet', Canberra: Centre for International Economics, March.

Broda, C.M. and D.E. Weinstein (2004), 'Globalization and the Gains from Variety', NBER Working Paper 10314, Cambridge MA, February.

Brown, D., A.V. Deardorff and R.M. Stern (2003), 'Multilateral, Regional and Bilateral Trade-Policy Options for the United States and Japan', The World Economy 26(6): 803-28, June. 
CEPII (2003), Methodological Tools for SIA: Report of the CEPII workshop held on 7-8 November 2002 in Brussels, Paris: CEPII Working Paper No. 2003-19. Download at http://www.cepii.fr/anglaisgraph/workpap/pdf/2003/wp03-19.pdf

Chua, A. (2003), World on Fire: How Exporting Free Market Democracy Breeds Ethnic Hatred and Global Instability, New York: Random House.

Cline, W.R. (2004a), Trade Policy and Global Poverty, Washington DC: Center for Global Development.

Cline, W.R. (2004b), 'Climate Change', paper prepared for the Copenhagen Consensus project, to be presented at a roundtable in Copenhagen 24-28 May.

Cline, W.R., T.O. Kawanabe, M. Kronsjo and T. Williams (1978), Trade Negotiations in the Tokyo Round: A Quantitative Assessment, Washington DC: Brookings Institution.

Coase, R. (1960), 'The Problem of Social Cost', Journal of Law and Economics 3:1-44.

Cole, M.A. (2003), 'Development, Trade, and the Environment: How Robust is the Environmental Kuznets Curve?' Environment and Development Economics 8(4): 557-80.

Copland, B. and M.S. Taylor (2003), Trade and the Environment: Theory and Evidence, Princeton NJ: Princeton University Press.

Corden (1979), 'Tell us Where the New jobs Will Come From', Bank of New South Wales Review Vol. 30, October. Reprinted in The World Economy 8(2): 183-88, June 1985, and as Ch. 7 in the author's The Road to Reform: Essays on Australian Economic Policy, Melbourne: Addison-Wesley, 1997.

Corden, W.M. (1997), Trade Policy and Economic Welfare (second edition), Oxford: Clarendon Press.

Das, G. (2001), India Unbound, New York: Knopf.

Deardorff, A.V. and R.M. Stern (1979), An Economic Analysis of the Effects of the Tokyo Round of Multilateral Trade Negotiations on the United States and Other Major Industrial Countries, MTN Studies 5, Washington DC: U.S. Government Printing Office.

Deardorff, A.V. and R.M. Stern (1986), The Michigan Model of World Production and Trade: Theory and Applications, Cambridge MA: MIT Press.

Devarajan, S., D.S. Go and H. Li (1999), 'Quantifying the Fiscal Effects of Trade Reform', World Bank Working Paper No. 2162, Washington DC, August.

Diebold, W., Jr. (1952), The End of the ITO, International Finance Section, Essays in International Finance No. 16, Princeton NJ: Princeton University Press.

Dimaranan, B., T. Hertel and R. Keeney (2003), 'OECD Domestic Support and the Developing Countries,' GTAP Working Paper No. 19, West Lafayette: Center for Global Trade Analysis, Purdue University.

Dimaranan, B.V. and R.A. McDougall (eds.) (2002), Global Trade, Assistance, and Production: The GTAP 5 Data Base, West Lafayette: Center for Global Trade Analysis, Purdue University.

Dixon, P., J. Menon and M. Rimmer (2000), 'Changes in Technology and Preferences: A General Equilibrium Explanation of Rapid Growth in Trade', Australian Economic Papers 39(1): 33-55, March.

Dollar, D. and A. Kraay (2002), 'Growth is Good for the Poor', Journal of Economic Growth 7(3): 195-225, September. 
Easterly, W. (2001), The Elusive Quest for Growth, Cambridge MA: MIT Press.

Ethier, W.J. (1996), 'Theories about Trade Liberalization and Migration: Substitutes or Complements?' pp. 50-68 in International Trade and Migration in the APEC Region, edited by P.J. Lloyd and L.S. Williams, London and Melbourne: Oxford University Press.

Evans, C. (2003), 'The Economic Significance of National Border Effects', American Economic Review 93(4): 1291-1312, September.

Feenstra, R.C., J.R. Markusen and W. Zeile (1992), 'Accounting for Growth with New Inputs', American Economic Review 82(2): 415-21, May.

Findlay, C. and T. Warren (2001), Impediments to Trade in Services: Measurement and Policy Implications, London and New York: Routledge.

FOE et al. (2003), Green Scissors 2003: Cutting Wasteful and Environmentally Harmful Spending available at http://www.foe.org/res/pubs/pdf/gs2003.pdf

Fontagné, L., J.-L. Guérin and S. Jean (2004), 'Market Access Liberalisation in the Doha Round: Scenarios and Assessment', mimeo, CEPII, Paris, January.

Francois, J.F. (1998), 'Scale Economies and Imperfect Competition in the GTAP Model,' GTAP Technical Paper 14, West Lafayette: Center for Global Trade Analysis, Purdue University, September.

Francois, J.F. (2000), 'Assessing the Results of General Equilibrium Studies of Multilateral Trade Negotiations', Policy Issues in International Trade and Commodities Study Series No. 3, Geneva: UNCTAD.

Francois, J.F. (2001), The Next WTO Round: North-South Stakes in New Market Access Negotiations, Adelaide: Centre for International Economic Studies and Rotterdam: Tinbergen Institute.

Francois, J.F. (2003), 'Assessing the Impact of Trade policy on Labour Markets and Production', pp. 61-88 in Methodological Tools for SIA, CEPII Working Paper No. 2003-19, Paris: CEPII.

Francois, J.F. and W. Martin (2003), 'Formula Approaches to Market Access Negotiations', The World Economy 26(1): 1-28, January.

Francois, J.F., H. van Meijl and F. van Tongeren (2003), 'Trade Liberalization and Developing Countries Under the Doha Round', CEPR Discussion Paper 4032, London, August.

Francois, J.F. and K.A. Reinert (eds.) (1997), Applied Methods for Trade Policy Analysis: A Handbook, Cambridge and New York: Cambridge University Press.

Frankel, J.A. and D. Romer (1999), 'Does Trade Cause Growth?' American Economic Review 89(3): 379-99, June.

Freeman, R.B. (2003), 'Trade Wars: The Exaggerated Impact of Trade in Economic Debate', Research Paper 2003/42, Leverhulme Centre for research on Globalizaation and Economic Policy, University of Nottingham.

Fujita, M., P. Krugman and A.J. Venables (2001), The Spatial Economy: Cities, Regions and International Trade, Cambridge MA: MIT Press.

Fujita, M. and J. Thisse (2002), Economics of Agglomeration: Cities, Industrial Location and Regional Growth, Cambridge and New York: Cambridge University Press.

Furusawa, T. and E.L.C. Lai (1999), 'Adjustment Costs and Gradual Trade Liberalization' Journal of International Economics 49: 333-61. 
Goldstein, J. (1998), 'International Institutions and Domestic Politics: GATT, WTO, and the Liberalization of International Trade', Ch. 4 in The WTO as an International Organization, edited by A.O. Krueger, Chicago and London: University of Chicago Press.

Greenaway, D. (1993), 'Liberalizing Foreign Trade Through Rose-Tinted Glasses', Economic Journal 103: 208-22.

Greenaway, D. and C. Milner (1993), 'The Fiscal Implication of Trade Policy Reform: Theory and Evidence', UNDP/World Bank Trade Expansion Program Occasional Paper 9, Washington, DC: World Bank.

Greenaway, D. and D.R. Nelson (eds.) (2002), Globalization and Labour Markets, (two volumes), London: Edward Elgar Publishers.

Grossman, G.M. and E. Helpman (1991), Innovation and Growth in the Global Economy, Cambridge, Mass.: MIT Press.

Grossman, G. and E. Helpman (1994), 'Protection for Sale', American Economic Review 84(4): 833-50, September.

Grossman, G. and E. Helpman (1995), 'Trade Wars and Trade Talks', Journal of Political Economy 103(4): 675-708, August.

Hamilton, B. and J. Whalley (1984), 'Efficiency and Distributional Implications of Global Restrictions on Labor Mobility', Journal of Development Economics 14: 61-75.

Harbaugh, W.T., A. Levinson and D.M. Wilson (2002), 'Re-examining the Empirical Evidence for an Environmental Kuznets Curve,' Review of Economics and Statistics 84(3): 541-51, August.

Harrison, G.W., T.F. Rutherford, D.G. Tarr and A. Gurgel (2003), 'Regional, Multilateral and Unilateral Trade policies on MERCOSUR for Growth and Poverty Reduction in Brazil', mimeo, World Bank, Washington DC, May.

Harrison, W.J., J.M. Horridge and K. Pearson (2000), 'Decomposing Simulation Results with Respect to Exogenous Shocks', Computational Economics 15: 227-49.

Hatton, T.J. and J.G. Williamson (1998), The Age of Mass Migration: Causes and Economic Impact, London and New York: Oxford University Press.

Hatton, T.J. and J.G. Williamson (2002), 'What Fundamentals Drive World Immigration?' CEPR Discussion Paper No. 3559, London, September.

Hertel, T.W. (ed.) 1997. Global Trade Analysis: Modeling and Applications, Cambridge and New York: Cambridge University Press.

Hertel, T.W., D. Hummels, M. Ivanic, and R. Keeney (2003), 'How Confident Can We Be in CGE-based Assessments of Free Trade Agreements?' GTAP Working Paper No. 26, West Lafayette: Center for Global Trade Analysis, Purdue University, May.

Hertel, T.W., M. Ivanic, P.V. Preckel and J.A.L. Cranfield (2003), 'Trade Liberalization and the Structure of Poverty in Developing Countries', Paper prepared for the Conference on Globalization, Agricultural Development and Rural Livelihoods, Cornell University, Ithaca, 11-12 April.

Hillman, A.L. (1989), The Political Economy of Protection, New York: Harwood Academic.

Hillman, A.L. and P. Moser (1995), 'Trade Liberalization as Politically Optimal Exchange of Market Access', in M. Canzoneri, W. Ethier and V. Grilli (eds.), The New Transatlantic Economy, Cambridge and New York: Cambridge University Press. 
Hoekman, B.M. and M. Kostecki (2001), The Political Economy of the World Trading System: The WTO and Beyond, Second Edition, London and New York: Oxford University Press.

Hoekman, B., F. Ng and M. Olarreaga (2002), 'Eliminating Excess Tariffs on Exports of Least Developed Countries', World Bank Economic Review 16: 1-21, January.

Hoekman, B., F. Ng and M. Olarreaga (2004), 'Agricultural Tariffs versus Subsidies: What's More Important for Developing Countries?' World Bank Economic Review 18 (forthcoming).

Hollander, J. (2003), The Real Environmental Crisis: Why Poverty, Not Affluence, is the Environment's Number One Enemy, Berkeley: University of California Press.

Ianchovichina, E. and R. McDougall (2000), 'Theoretical Structure of Dynamic GTAP', GTAP Technical Paper No. 17, West Lafayette: Center for Global Trade Analysis, Purdue University.

Ianchovichina, E., A. Mattoo and M. Olarreaga (2001), 'Unrestricted Market Access for Sub-Saharan Africa: How Much is it Worth and Who Pays? CEPR Discussion Paper No. 2820, London: Centre for Economic Policy Research, June.

Irwin, D.A. (1996), Against the Tide: An Intellectual History of Free Trade, Cambridge MA: MIT Press.

Irwin, D.A. (2002), Free Trade Under Fire, Princeton: Princeton University Press.

Jacobson, L.S., R.J. LaLonde and D.G. Sullivan (1993), 'Earnings Losses of Displaced Workers', American Economic Review 83(4): 685-709, September.

Just, R.E., D.L. Hueth and A. Schmitz (1982), Applied Welfare Economics and Public Policy, Englewood Cliffs NJ: Prentice-Hall.

Kindleberger, C.P. (1989), 'Commercial Policy Between the Wars', in Peter Mathias and Sidney Pollard (eds.), The Cambridge Economic History of Europe, vol. 8. Cambridge: Cambridge University Press.

King, D.K. (2003), GM Science Review: First Report, Prepared by the GM Science Review Panel under the chairmanship of Sir David King for the UK Government, July.

Krueger, A.B. and J. Maleckova (2002), 'Education, Poverty, Political Violence and Terrorism: Is There a Causal Connection?' NBER Working Paper No. 9074, Cambridge MA, July.

Krueger, A.O. (1983), Trade and Employment in Developing Countries, Volume 3: Synthesis and Conclusions, Chicago: University of Chicago Press for NBER.

Krueger, A.O. (1999), 'Free Trade Agreements as Protectionist Devices: Rules of Origin', pp. 91-102 in Trade Theory and Econometrics: Essays in Honour of John S. Chipman, edited by J. Melvin, J. Moore and R. Riezman, London: Routledge.

Lee, J.-W. (1995), 'Capital Goods Imports and Long-Run Growth', Journal of Development Economics 48: 91-110, October.

Lomborg, B. (2001), The Skeptical Environmentalist: Measuring the Real State of the World, Cambridge and New York: Cambridge University Press.

Lucas, R.E. Jr. (2002), Lectures on Economic Growth, Cambridge MA: Harvard University Press.

Magee, S.P. (1972), 'The Welfare Effects of Restrictions on US Trade', Brookings Papers on Economic Activity 3: 645-701. 
Maggi, G. and A. Rodrigeuz-Clare (1998), 'The Value of Trade Agreements in the Presence of Political Pressures', Journal of Political Economy 106(3): 574-601, June.

Markusen, J.R. (1983), 'Factor Movements and Commodity Trade as Complements', Journal of International Economics 13: 341-56.

Martin, W. (1997), 'Measuring Welfare Changes with Distortions', Ch. 3 in Applied Methods for Trade Policy Analysis: A Handbook, edited by J. Francois and K. Reinert, Cambridge and New York: Cambridge University Press.

Martin, W. and L.A. Winters (eds.) (1996), The Uruguay Round and the Developing Countries, Cambridge and New York: Cambridge University Press.

Maskus, K. and J. Wilson (eds.) (2001), Quantifying the Impact of Technical Barriers to Trade: Can it be Done? Ann Arbor: University of Michigan Press.

Mattoo, A. and A. Subramanian (2003), 'What Would a Development-Friendly WTO Architecture Really Look Like?' IMF Working Paper WP/03/153, Washington DC, August.

Matusz, S. and D. Tarr (2000), 'Adjusting to Trade Policy Reform', in Economic Policy Reform: The Second Stage, edited by A.O. Krueger, Chicago: University of Chicago Press.

Mazumdar, J. (2001), 'Imported Machinery and Growth in LDCs', Journal of Development Economics 65: 209-224, June.

McCulloch, N., L.A. Winters and X. Cirera (2001), Trade Liberalization and Poverty: A Handbook, London: Centre for Economic Policy Research.

McDougall, R., A. Elberhnri and T.P. Truong (eds.) (1998), Global Trade, Assistance, and Protection: The GTAP 4 Data Base, West Lafayette: Center for Global Trade Analysis, Purdue University, December.

Melitz, M. (1999), 'The Impact of Trade on Intra-industry Reallocations and Aggregate Industry Productivity', Economics Working Paper, Harvard University, Cambridge MA, November.

Melo, J. de and D. Tarr (1990), 'Welfare Costs of US Quotas on Textiles, Steel and Autos', Review of Economics and Statistics 72: 489-97.

Michaely, M. (2003), 'Goods versus Factors: When Borders Open, Who Moves?' The World Economy 26(4): 533-54, April.

Michaely, M., D. Papageorgiou and A. Choksi (eds.) (1991), Liberalizing Foreign Trade, 7: Lessons of Experience in the Developing World, Cambridge MA and Oxford: Basil Blackwell.

Milner, C. and P. Wright (1998), 'Modeling Labour Market Adjustment to Trade Liberalization in an Industrializing Country', Economic Journal 108: 509-28, March.

Moltke, A. von, C. McKee and T. Morgan (2004), Energy Subsidies: Lessons Learned in Assessing Their Impact and Designing Policy Reforms, London: Greenleaf Books for UNEP.

Mundell, R.A. (1957), 'International Trade and Factor Mobility', American Economic Review 47: 321-35.

Myers, N. and J. Kent (1998), Perverse Subsidies: Tax Dollars undercutting our Economies and Environments Alike, Winnipeg: International institute for Sustainable Development. 
Nash, J. and W. Takacs (1998), 'Lessons from the Trade Expansion Program', Ch. 1 in Trade Policy Reform: Lessons and Implications, edited by J. Nash and W. Takacs, Washington DC: World Bank.

Neary, J.P. (2001), 'Of Hype and Hyperbolas: Introducing the New Economic Geography,' Journal of Economic Literature 39(2): 536-61, June.

Ng, Y.-K. (1983), Welfare Economics, London: Macmillan.

Nielsen, C.P. (2003), Regional and Preferential Trade Agreements: A Literature Review and Identification of Further Steps, Report No. 155, Copenhagen: Danish Research Institute of Food Economics, November.

OECD (1996), Subsidies and the Environment: Exploring the Linkages, Paris: OECD.

OECD (1997), Reforming Energy and Transport Subsidies: Environmental and Economic Implications, Paris: OECD.

OECD (1998), Improving the Environment Through Reducing Subsidies, Paris: OECD.

OECD (2003a), Agricultural Trade and Poverty: Making Policy Analysis Count, Paris: OECD.

OECD (2003b), Environmentally Harmful Subsidies: Policy Issues and Challenges, Paris: OECD.

Olsen, M. (1965), The Logic of Collective Action, Cambridge MA: Harvard University Press.

Oneal, J. and B. Russett (2000), Triangulating Peace: Democracy, Interdependence and International Organizations, New York: Norton.

Oxfam (2002), 'Boxing Match in Agricultural Trade: Will WTO Negotiations Knock Out the World's Poorest Farmers?' Briefing Paper 32, Brussels: Oxfam International.

Panagariya, A. (2004), 'Miracles and Debacles: Do Free-trade Skeptics Have a Case?' The World Economy 27 (forthcoming).

Pomfret, R. (1997), The Economics of Regional Trading Arrangements, London: Oxford University Press.

Rae, A.N. and A. Strutt (2003), 'The Current Round of Agricultural Trade Negotiations: Should We Bother About Domestic Support?' Estey Centre Journal of International Law and Trade Policy 4(2): 98-122.

Rivera-Batiz, L. and P. Romer (1991), 'International Integration and Endogenous Growth', Quarterly Journal of Economics 106: 531-56.

Rodrigeuz, F. and D. Rodrik (2001), 'Trade Policy and Economic Growth: A Skeptic's Guide to Cross-National Evidence', in B.S. Bernanke and K. Rogoff (eds.), NBER Macroeconomics Annual 2000, Cambridge MA: MIT Press.

Rodrik, D. (2003), 'Growth Strategies', NBER Working Paper 10050, Cambridge MA, October.

Rogoff, K.S. (2003), 'Disinflation: An Unsung Benefit of Globalization,' Finance and Development 40(4): 54-55, December.

Romer, P. (1986), 'Increasing Returns and Long-Run Growth,' Journal of Political Economy 94(5): 1002-37, October.

Romer, P. (1994), 'New Goods, Old Theory, and the Welfare Costs of Trade Restrictions,' Journal of Development Economics 43(1): 5-38,

Runge, C.F., B. Senauer, P.G. Pardey and M.W. Rosegrant (2003), Ending Hunger in Our Lifetime: Food Security and Globalization, Baltimore and London: Johns Hopkins University Press for IFPRI. 
Rutherford, T.F. and D.G. Tarr (2002), 'Trade Liberalization, Product Variety and Growth in a Small Open Economy: A Quantitative Assessment', Journal of International Economics 56(2): 247-72, March.

Sachs, J.D. and A. Warner (1995), 'Economic Reform and the Process of Global Integration', Brookings Papers on Economic Activity 1: 1-95.

Sala-i-Martin, X. (2002), 'The World Distribution of Income (Estimated from Individual Country Distributions)', NBER Working Paper 8933, Cambridge MA, May.

Schiff, M. and L.A. Winters 2003), Regional Integration and Development, London and New York: Oxford University Press for the World Bank.

Taylor, M.S. (1999), 'Trade and Trade Policy in Endogenous Growth Models', Ch. 15 in International Trade Policy and the Pacific Rim, edited by J. Piggott and A. Woodland, London: Macmillan for the IAE.

Trefler, D. (2001), 'The Long and Short of the Canada-US Free Trade Agreement', NBER Working Paper No. 8293, May.

UNCTAD/Commonwealth Secretariat (2001), Duty and Quota Free Market Access for LDCs: An Analysis of Quad Initiatives, Geneva: UNCTAD and London: Commonwealth Secretariat.

USITC (1997), The Dynamic Effects of Trade Liberalization: An Empirical Analysis, Investigation No. 332-375, Publication 3069, Washington, D.C.: Unites States International Trade Commission, October.

Verikios, G. and X.-G. Zhang (2001), Global Gains from Liberalizing Trade in Telecommunications and Financial Services, Staff Research Paper, Canberra: Productivity Commission.

Wacziarg, R. (2001), 'Measuring the Dynamic Gains From Trade' World Bank Economic Review 15(3): 393-429, October.

Wacziarg, R. and K.H. Welch (2003), 'Trade Liberalization and Growth: New Evidence', NBER Working Paper 10152, Cambridge MA, December.

Whalley, J. (1985), Trade Liberalization Among Major World Trading Areas, Cambridge MA: MIT Press.

Whalley, J. (2000), 'What Can the Developing Countries Infer from the Uruguay Round Models for Future Negotiations?' Policy Issues in International Trade and Commodities Study Series No. 4, Geneva: UNCTAD.

Whalley, J. (2003), 'Assessing the Benefits to Developing Countries of Liberalization in Services Trade', NBER Working Paper 10181, Cambridge MA, December.

Williamson, J.G. (2002), 'Winners and Losers Over Two Centuries of Globalization', WIDER Annual Lecture 6, United Nations University, Helsinki.

Winters, L.A. (2002), 'Trade Liberalisation and Poverty: What Are the Links?' The World Economy 25(9): 1339-68, September.

Winters, L.A., N. McCulloch and A., McKay (2004), 'Trade Liberalization and Poverty: The Empirical Evidence', Journal of Economic Literature 62 (forthcoming).

Winters, L.A. and W.E. Takacs (1991), 'Labour Adjustment Costs and British Footwear Protection', Oxford Economic Papers 43: 479-501.

Winters, L.A., T. Walmsley, Z.K. Wang and R. Grynberg (2003), 'Liberalizing Temporary Movement of Natural Persons: An Agenda for the Development Round', The World Economy 26(8): 1137-61, August. 
World Bank (2002), Global Economic Prospects and the Developing Countries 2002: Making Trade Work for the Poor, Washington D.C.: The World Bank.

World Bank (2003), Global Economic Prospects 2004: Realizing the Development Promise of the Doha Agenda, Washington D.C.: The World Bank, September.

WWF (2001), Hard Facts, Hidden Problems: A Review of Current Data on Fisheries Subsidies, Washington DC: WWF. 

Table 1: Comparative static estimates of economic welfare gains from full global liberalization of goods and services trade

\begin{tabular}{|c|c|c|c|c|c|c|}
\hline Study & $\begin{array}{r}\text { Market } \\
\text { assumptions }^{\mathrm{a}}\end{array}$ & $\begin{array}{r}\text { Sectors } \\
\text { liberalized }\end{array}$ & $\begin{array}{r}\text { Baseline year } \\
\text { (of EV welfare } \\
\text { measure) }\end{array}$ & $\begin{array}{r}\text { Welfare gain, } \\
\text { non-OECD } \\
\text { (US\$ billions) }\end{array}$ & $\begin{array}{r}\text { Welfare gain, } \\
\text { global } \\
\text { (US\$ billions) }\end{array}$ & $\begin{array}{r}\text { Year of } \\
\text { currency } \\
\text { (US dollars) }\end{array}$ \\
\hline ADFHHM (2002) & $\mathrm{CRS} / \mathrm{PC}$ & Goods only & 2005 & 108 & 254 & 1995 \\
\hline BDS (2003) & IRS/MC & $\begin{array}{r}\text { Goods, } \\
\text { services } \\
\text { and FDI }\end{array}$ & 2005 & 431 & 2080 & 1995 \\
\hline FMT (2003) & IRS/MC & $\begin{array}{r}\text { Goods and } \\
\text { services }\end{array}$ & 1997 & 113 & 367 & 1997 \\
\hline WBGEP (2003) & $\mathrm{CRS} / \mathrm{PC}$ & Goods only & 2015 & 184 & 355 & 1997 \\
\hline WBGEP (2003) & $\begin{array}{r}\mathrm{CRS} / \mathrm{PC} \text { plus } \\
\text { productivity } \\
\text { boost }\end{array}$ & Goods only & 2015 & 539 & 832 & 1997 \\
\hline
\end{tabular}

\footnotetext{
a Constant returns to scale/perfect competition and increasing returns to scale/monopolistic competition/firm-level differentiated products.
}

Sources: Anderson et al. (2002); Brown, Deardorff and Stern (2003); Francois, van Meijl and van Tongeren (2003); and World Bank (2003). 

Table 2: Sectoral and regional ${ }^{\mathrm{a}}$ contributions to comparative static estimates of economic welfare gains from completely removing goods trade barriers globally, postUruguay Round, 2005

$$
\text { (percent of total global gains) }
$$

\begin{tabular}{|c|c|c|c|c|c|}
\hline Liberalizing & Agriculture & Other & Textiles \& & Other & Total \\
\hline $\begin{array}{r}\text { Benefitting } \\
\text { region }\end{array}$ & and Food & Primary & Clothing & Manufactures & \\
\hline High Income & & & & & \\
\hline High Income & 43.4 & 0.0 & -2.3 & -3.2 & 38.0 \\
\hline Low Income & 4.6 & 0.1 & 3.5 & 8.8 & 16.9 \\
\hline Total & 48.0 & 0.0 & 1.3 & 5.6 & 54.9 \\
\hline Low Income & & & & & \\
\hline High Income & 4.4 & 0.1 & 4.1 & 10.9 & 19.5 \\
\hline Low Income & 12.3 & 1.0 & 1.4 & 10.9 & 25.6 \\
\hline Total & 16.7 & 1.1 & 5.5 & 21.7 & 45.1 \\
\hline All Countries & & & & & \\
\hline High Income & 47.9 & 0.1 & 1.9 & 7.7 & 57.5 \\
\hline Low Income & 16.9 & 1.0 & 4.9 & 19.6 & 42.5 \\
\hline Total & 64.8 & 1.1 & 6.8 & 27.3 & 100.0 \\
\hline
\end{tabular}

${ }^{a}$ High and low income here are short-hand for developed and developing countries.

Source: Anderson et al. (2002). 

Table 3: Comparative static estimates of economic welfare gains from a 50 percent multilateral liberalization of goods and services trade (optimistic Doha Round) and from the proposed FTAA

\begin{tabular}{|c|c|c|c|c|c|c|c|}
\hline Study & $\begin{array}{r}\text { Market } \\
\text { assumptions }^{\text {a }}\end{array}$ & $\begin{array}{r}\text { Sectors } \\
\text { liberalized }\end{array}$ & $\begin{array}{r}50 \% \text { cut to } \\
\text { bound or } \\
\text { applied } \\
\text { tariffs? }\end{array}$ & $\begin{array}{r}\text { Baseline year } \\
\text { (of EV welfare } \\
\text { measure) }\end{array}$ & $\begin{array}{r}\text { Welfare gain, } \\
\text { non-OECD } \\
\text { (US\$ billions) }\end{array}$ & $\begin{array}{r}\text { Welfare gain, } \\
\text { global } \\
\text { (US\$ billions) }\end{array}$ & $\begin{array}{r}\text { Year of } \\
\text { currency } \\
\text { (US dollars) }\end{array}$ \\
\hline \multicolumn{8}{|c|}{ (a) Optimistic Doha round } \\
\hline $\operatorname{BDS}(2003)$ & IRS/MC & $\begin{array}{r}\text { Goods and } \\
\text { services } \\
\text { incl. FDI }\end{array}$ & Applied & 2005 & 216 & 1040 & 1995 \\
\hline FMT (2003) & IRS/MC & $\begin{array}{r}\text { Goods and } \\
\text { services }\end{array}$ & Bound & 1997 & 88 & 196 & 1997 \\
\hline FMT (2003) & $\mathrm{CRS} / \mathrm{PC}$ & $\begin{array}{r}\text { Goods and } \\
\text { services }\end{array}$ & Bound & 1997 & 51 & 132 & 1997 \\
\hline HRTG (2003) & $\mathrm{CRS} / \mathrm{PC}$ & Goods only & Applied & 1997 & 97 & 186 & 1996 \\
\hline \multicolumn{8}{|l|}{ (b) $F T A A$} \\
\hline BDS (2003) & IRS/MC & $\begin{array}{r}\text { Goods and } \\
\text { services } \\
\text { incl. FDI }\end{array}$ & Applied & 2005 & 24 & 83 & 1995 \\
\hline HHIK (2003) & $\mathrm{CRS} / \mathrm{PC}$ & Goods only & Applied & 1997 & na & 3 & 1997 \\
\hline HRTG (2003) & $\mathrm{CRS} / \mathrm{PC}$ & Goods only & Applied & 1997 & 6 & 4 & 1996 \\
\hline
\end{tabular}

${ }^{\text {a }}$ CRS/PC: constant returns to scale/perfect competition; IRS/MC: increasing returns to scale/monopolistic competition/firm-level differentiated products. Sources: Brown, Deardorff and Stern (2003); Francois, van Meijl and van Tongeren (2003); Hertel, Hummels, Ivanic, and Keeney (2003); and Harrison, Rutherford, Tarr and Gurgel (2003). 

Table 4: Summary of benefits and costs of liberalizing subsidies and trade barriers

(2002 US\$ billion)

$\begin{array}{ccccc}\text { Opportunity }^{\text {a }} & \begin{array}{c}\text { Benefit } \\ \text { (net } \\ \text { present } \\ \text { value in } \\ \text { 2005) }\end{array} & \begin{array}{c}\text { Cost (net } \\ \text { present } \\ \text { value in }\end{array} & \begin{array}{c}\text { Benefit/ } \\ \text { cost }\end{array} & \text { Key assumptions } \\ & & & \end{array}$

\begin{tabular}{|c|c|c|c|c|}
\hline $\begin{array}{l}\text { Optimistic Doha: } \\
50 \% \text { liberalization of } \\
\text { trade barriers and } \\
\text { agricultural subsidies }\end{array}$ & $\$ 23,040$ & $\$ 947$ & 24.3 & $\begin{array}{l}5 \% \text { discount rate, } \\
\text { benefits rise each year } \\
\text { even after the five-year } \\
\text { phase-in to } 2010 \\
\text { (because the economy } \\
\text { is growing) and last to } \\
2050 \text {, costs are } \$ 219 \\
\text { billion per year and } \\
\text { last from } 2006 \text { to } 2010\end{array}$ \\
\hline $\begin{array}{l}\text { Full reform: } \\
100 \% \text { liberalization } \\
\text { of trade barriers and }\end{array}$ & $\$ 46,080$ & $\$ 2,104$ & 21.9 & $\begin{array}{l}\text { As above except costs } \\
\text { are } \$ 583 \text { billion per } \\
\text { year }\end{array}$ \\
\hline
\end{tabular}

agricultural subsidies

Pessimistic Doha:

$\$ 11,520 \quad \$ 395$

29.2

As above except costs

$25 \%$ liberalization of

trade barriers and

agricultural subsidies

${ }^{a}$ Based on the estimates in the BDS study, the FTAA opportunity would yield benefits of (possibly very much) less than one-twelfth of that for the Optimistic Doha opportunity above, and a lower benefit/cost ratio, because of standard FTA complexities such as rules of origin. The EBA opportunity for least-developed countries to get preferential (dutyand quota-free) access to developed country markets would yield global benefits of less than one-hundredth of the above, and those benefits would diminish as and when developed countries lowered their MFN tariffs. While the least-developed countries would be the main beneficiaries in proportional terms from EBA, their benefit would be at the expense of other developing countries (including ones as poor as Vietnam) who lose from the trade-diverting nature of this preferential agreement. 

Figure 1: Annual increment to global GDP without and with 50\% cut to subsidies and trade barriers, 2006 to 2050

(in billions of 2002 US dollars)

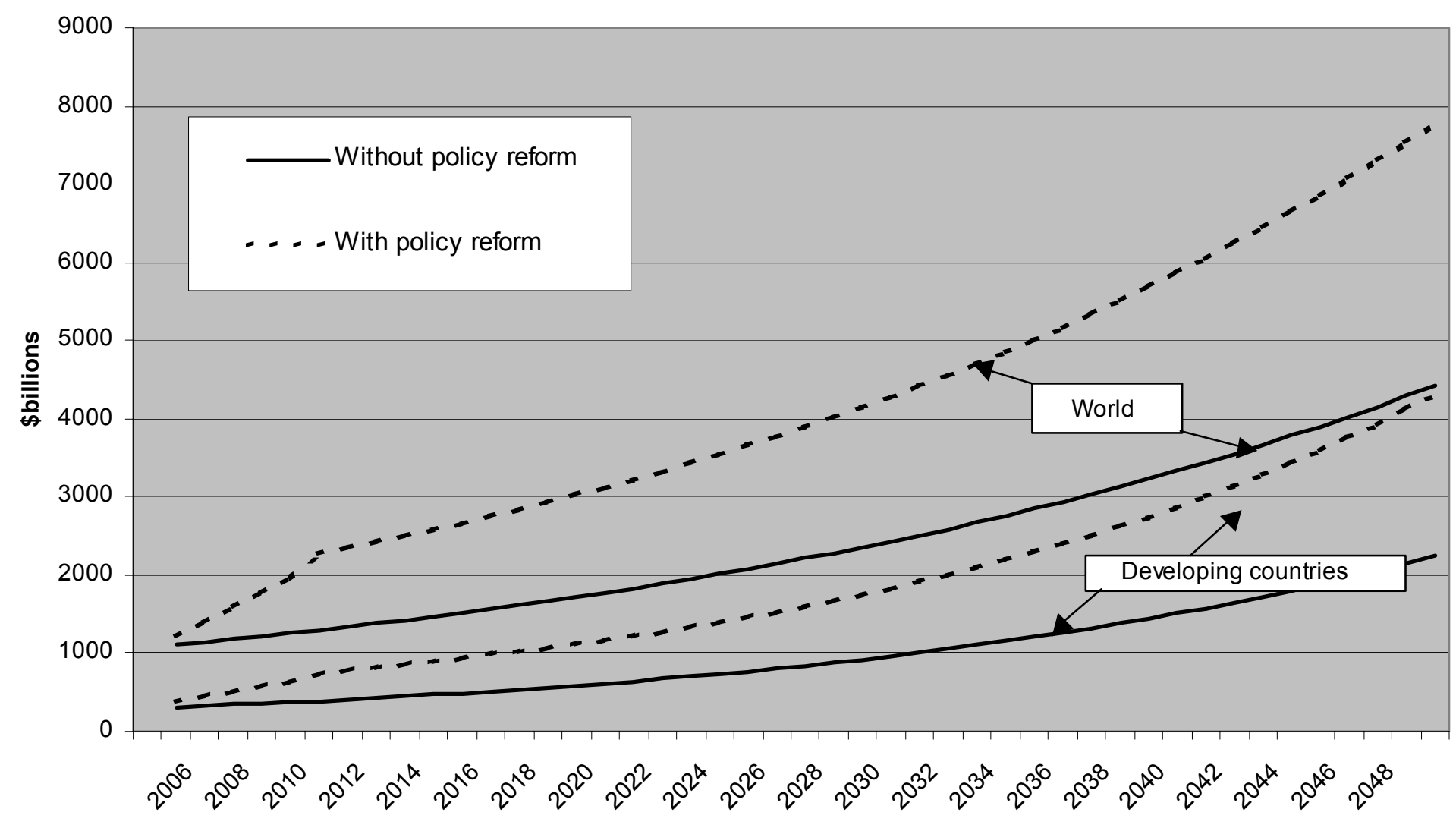

